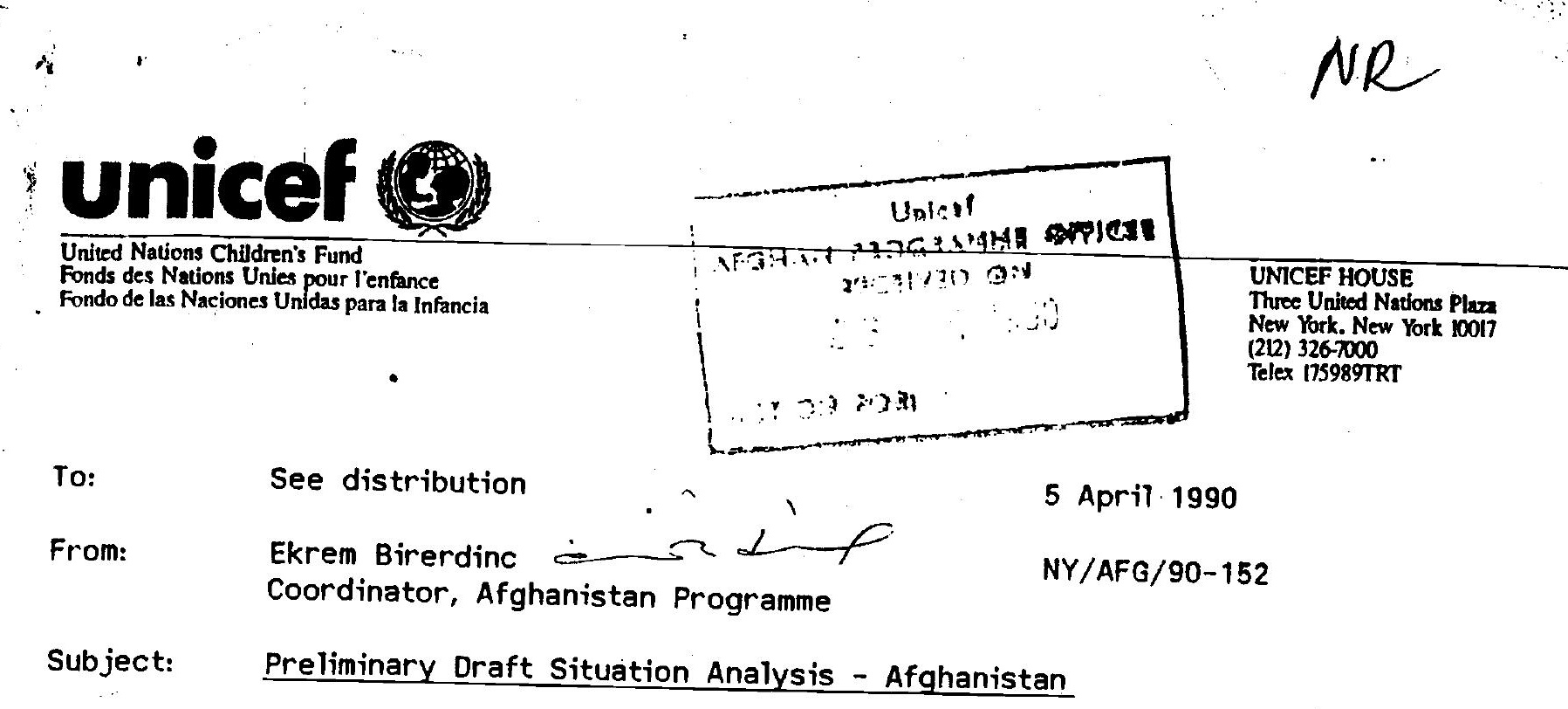

Attached is an advance copy of a Preliminary Draft Situation Analysis of Afghan Children and Women. Prior to a much wider distribution, I would be grateful for your comments and substantive and detailed analysis to be prepared later this year, as supporting documentation for the 1991 Executive Board presentation.

\author{
Distribution \\ Dr. R. Jolly \\ Dr. Nyi Nyi \\ Mr. H. Narula \\ Mr. R. Reid \\ Mr. K.E. Knutsson \\ Mr. D. Brooks \\ Mrs. R. Padmini \\ Mr. T. Hidalgo \\ Mr. T. Hill \\ Mr. B. Oldeaus \\ Ms. M. Khan \\ Mr. K. Waki \\ Mr. T. Carter \\ Mr. L. Rosenhall \\ Mr. G. Andersson \\ Mr. C. La Munière
}


Bibllography

Tables

Page

Table 1 Afghanistan Comparative Population Estimates:

Table 2 Province of origin: Afghan Refugees in

Table 3 Pakistan

Table 4

Sex Ratios and Life Expectancies in Afghanistan 15

Table 5

Table 6

Population Projections Afghanistan to 2010

Age structure Afghanistan 1354 (1975)

Infant, Child and Maternal Mortality by
Live Births

Table 7

Proportion of Mortality due to Four Major
Causes (1970's)

Table 8

Principal Causes of Morbidity (by age)

Table 9

Major Diagnoses Reported in Children Und

(1988) by Health Workers

Table 10

Diagnoses of Women (15-44)

Table 11

Table 12

Table 13

Protein Energy Malnutrition Children 0-5

Health Service Expenditure by Target Group

Table 14

Health Facilities and Population Ratios outside

Table 15

Table 16

Afghan Literacy Rates

Comparative Indicators of Access to Primary
Education 1979 and 1988

Table 17

Table 18

Teachers in Primary schools

Table 19

Number of Secondary Schools

Gross Domestic Product at Constant 1978/79
Prices

Figures

Figure 1 Total Midyear Population 1979-1990

Figure 2 Year of Leaving Afghanistan (Refugees in Pakistan)

Appendj.x I

Table 1 Sickness in Past Two Weeks as Reported by
Respondents in a Health Survey of Three Afghan Provinces by Age and Sex (1977)

* Table 2

Health Infrastructure in Afghanistan (1989)

* Table 3

Medical Facilities in Afghanistan (1988) Supporting Cross Border

Table 4

Age-Sex Pyramid Total Age Distribution

Appendix II

Map 1

Map 2

Afghanistan Roads

Map 3

Ethnic Groups

Approximate Locations of Internally Displaced

* Not yet included 
Map of Afghanistan

Afghanistan: Land, People, Economy

Introduction

Page

Part I - 1978-1989 Civil strife and Dislocation

1.0 Overview

2.0 Pre-1978 Afghanistan

3.0 From Revolution to Rebellion

4.0 Principal Events of the War

5.0 The Accords

6.0 Current situation

7.0 Consequences of War

Part II - Demography

1.0 Overview

2.0 Population Data

3.0 Gender Differentials

4.0 Fertility and Potential for Population Growth

5.0 Age Structure and Dependency

6.0 The Demographic Profile and Planning for Children and Women

$$
\text { - situation of Afghan children and nomen - Health }
$$

Part III - situation of Afghan Children and women - Health

1.0 Mortality

2.0 Morbidity

3.0 Trends in Mortality and Morbidity

4.0 Nutritional status

5.0 Underlying Causes of Mortality, Morbidity and

6.0 Malnutrition

IV - Education

Part IV - Education

2.0 Principal Indicators of the Basic Education situation

4

Part $\nabla$ - Enduring structural constraint on Health

and Education Development for Children and Fomen

1.0 Overview

2.0 Poverty

3.0 Modernization versus Tradition; Central Authority

4.0 Patriarchical Attitudes and Practices

5.0 Cultural and Geographic Isolation

Part VI - Problems, Constraints, opportunities

1.0 Problems: a Reprise

2.0 Target Groups

3.0 Constraints, opportunities, Modalities 


\section{ArGHANI 8TAN}

LANP - Afghanistan is a landlocked nation bordered by Iran in the China on a small section south and east, the USSR in the north and Geography has isolated Afghan wakhan corridor in the Northeast. occurring in the rest of the world fom economic and social changes economy and communications. Torld, and shapes internal climate, 653,000 square kilometers. The Hindu Kush mountains dominate its hot summers and cold winters. The severe continental climate brings in the deserts to over $1100 \mathrm{~mm}$ in tipitation, ranging from $75 \mathrm{~mm}$ the winter and as snow in the higher altitudes comes mostly in country's five major river systems irrigation. The nearest sear systems which provide water for Kabul.

PEOPLE - The total number of Afghans is estimated at 19.4 million; 14.2 are inside the country and approximately 5.2 million are refugees in Pakistan and Iran. An estimated 1-1.5 million people large numbers of disabled, org civil war, which also leaves behind rates are among the highest orphans and widows. Infant mortality some rural and refugee areas and 135 orld, perhaps 284 per 1000 in rates are high and thought to have increased Kabul. Fertility population. Literacy rates are low: increased among the refugee 1970 's.

ECoroMY - A least developed country, the per capita GDP was sector producing 458 of GDP. Since the biculture is the principal Afghanistan, GDP is thought to have declined at year. War has destroyed or damaged much ate of $2.6 \%$ per infrastructure and productive capacity, including af ishanistan's systems, roads, schools, health facilitiés, and including irrigation estimated that the country's limited is consumed at a rate ten times its capacity for regeneration being 


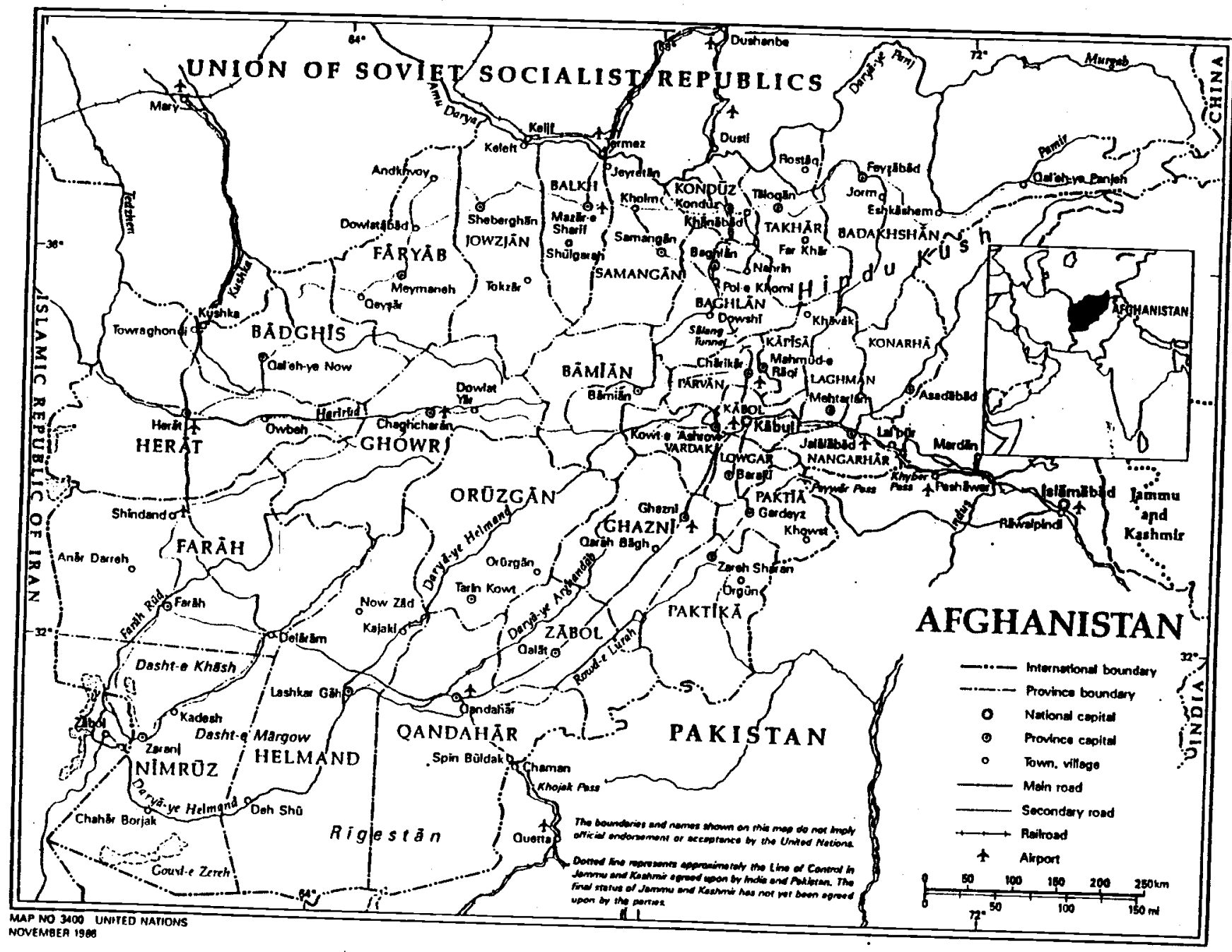




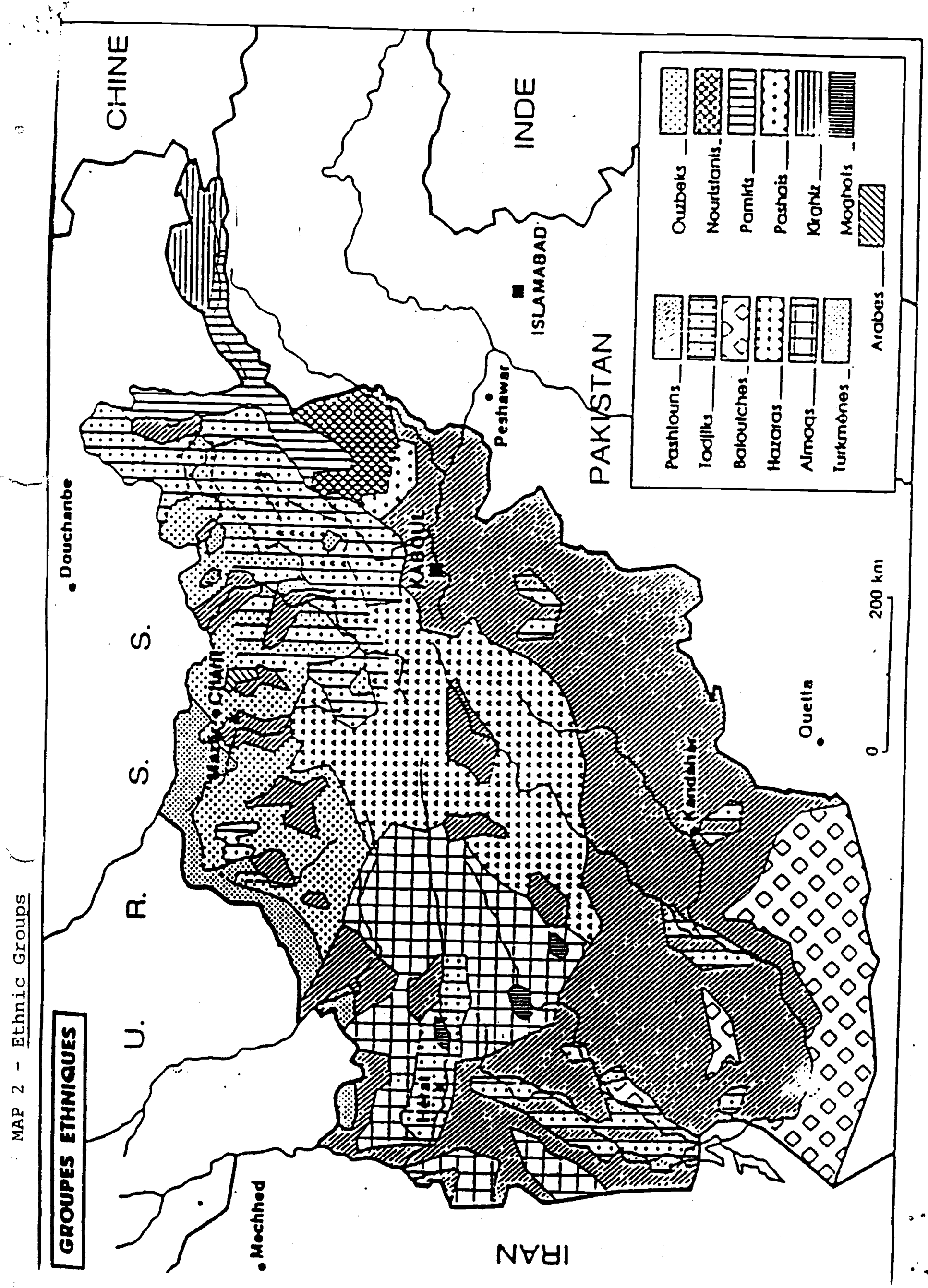


remain. Divisiveness prevents the establishment of a national civil authority acceptable to all, in the absence of which warfare continues. Of the innocent people caught in the continuing crossfire, children and women are most vulnerable, and face the prospect even of famine in certain parts of the country.

The Afghan people face a daunting task; that of bullding national reconciliation and of starting the long task of reconstruction and development.

Within that context, UNICEF has a challenging role. On the one hand, it is charged with serving the immediate needs of children and women who are among the world's most vulnerable. And it must do this in a situation where emergency conditions have not yet been resolved. On the other hand, UNICEF seeks to use its interventions now to lay the foundation for sustained development in the future.

Before looking to the future, it is instructive to know as much as possible about the present and to understand the past which shapes or impinges on the future. Part I of this Analysis provides a brief overview of the recent history of Afghanistan, and of the social, political and military events which have produced a massive disruption of national life, the destruction of rural areas and the dislocation internally and abroad of more than a third of the national population.

The breakdown of national life and the dispersion of population ended any reality of national statistics. Part II reviews the demographic data and estimates available, including census data from the $1970^{\prime} \mathrm{s}$, estimates on current population and its breakdown by location and gender, as well as the implications of population projections for the future, the effect of high dependency ratio and of gender differentiations in the data and the evidence identifying particularly vulnerable groups.

Part III and IV of this situation Analysis seek to specify what is known about the status of children and mothers today, to isolate trends in the past 25 years, and to identify immediate causes of this situation. They examine and assess avallable data on the standard indicators of health, nutrition and education status of children and women. Assessment, where possible, is broken down by gender and by location, seeking to pinpoint the most vulnerable groups by the categories established in part II. It then identifies the existing health services, food security, dominant health practices and attitudes and social structures which contribute to the vulnerable position of Afghan children and women.

Part $\nabla$ returns to the underlying and structural factors which will continue to affect efforts to introduce improvements in the situation of children and women. Within an historical perspective, it describes the durability of these factors in relation to the war and of population movements. 
Part VI examines the opportunities for improving the situation of and militard women, within the context of an uncertain political and military situation, and the difficulties of projecting refugee
return.

The situation Analysis has relled heavily on a wealth of studies undertaken or collected by UNICEF offices in Peshawar and Kabul, scholars. It uses material aped by other UN agencies and by Planning and Afghan Women August the UNIFEM-UNICEF Workshop of resources is attached. E A bibllography of McDermott and other staff of given continuing and creative Afghan Unit, UNICEF, New York have

Susan Hol combe Consultant 
PART I - 1978-1989 - CIVIL 8TRIFE AND DIBLOCATION

\subsection{OVERVIET}

The upheaval of the past decade is of a scale and scope unprecedented in Afghan history. Perhaps 98 of the population has been killed, and an unestimated number disabled (cf. sliwinski 1989). Three to five million mines have been planted in the countryside. More than a third of the population has been uprooted as internal and external refugees. Bombing has destroyed homes and livel thood, driving families into exile. A new generation has been born, never seeing its homeland at the same time an older generation still experiences the trauma and emotional shock of the war. While these human costs cannot be readily measured, inability to do so should not be a reason for ignoring them.

Agricultural output is perhaps 458 of 1978 levels, while animal wealth may have been reduced by one half or two thirds (Economic Intelligence Unit $3 / 1988$ ). Up to $80 \%$ of rural infrastructure, including schools and health facilities, has been destroyed. Accurate measures of GDP are not posisible, but the destruction of the country's agricultural base has left both the Government in Kabul and the refugee population heavily dependent on outside aid for subsistence and survival. The remaining rural population has little access to outside support for survival.

Minimal conditions for maintaining or improving child health and development have ceased to exist for most Afghans.

The situation leading up to the saur Revolution in 1978 and the consequent breakdown of national order are the background of the current situation of children and women, as well as a factor exacerbating the age old tensions between central and local authority and modernizing and traditional impulses in Afghanistan

\subsection{PRE-1978 AFGHANISTAN}

Much of what has been written about the Daoud Government, which immediately preceded the Saur Revolution of 27 April 1978, focuses on internal and external political and military issues and the impact of Cold War rivalries. There is little analysis of social policies and practices. While power interests were and remain a reality in national stablilty, health, education and other social policies and practices contribute to the perceived legitimacy of government at whatever level. In the 1970 's health and education development in Afghanistan was a low priority.

Mohammed Daoud came to power in Afghanistan in a 1973 coup. Ten years (1963-1973) of an experiment with Parliamentary democracy had 
bogged down; political inaction paralyzed Government. A drought in 1971-72 had reduced wheat and other crop production by an estimated 20\%, while livestock numbers fell by as much as $40 \%$. Food aid arrived, but inefficiencies and corruption prevented its reaching intended beneficiaries. Up to 500,000 people may have died in the resulting famine. In 1972, the World Bank noted "The past fifteen years have been frustrating and disappointing... A relatively large volume of aid sustained high levels of investment to little visible purpose in terms of higher standards of living for the vast majority of the population."

The coup that brought Daoud to the Presidency in 1973 was supported by leftists interested in social change. Development policies which followed, however, continued to focus on investment in industry, particularly on the development of heavy industries based on minerals and other resources. Afghanistan's First Seven-Year Economic and Social Development plan projected investment for heavy industries, mines and energy at 378 of the total; transportation 32\%; agriculture $25 \% ;$ and only $6 \%$ for social services. Social services were given low priority in the plan and in development and operating expenditures. In 1977/78, for example, an overall decrease of $1.3 \%$ in health expenditures was mandated. 'Application of the cuts, to Immunisation, TB/leprosy, Malaria, and Basic Health Services programmes, with a simultaneous increase of $9 \%$ to Hospitals, reflected an endemic blas toward urban areas and curative hospltal services (World Bank 1978:203). A Management Sclences for Health Financlal Analys is of Health Programmes in 1977 suggested that the largest portion of health expenditure (53.98) benefitted the population group least at risk (labour force); while infants, children and especially mothers received the smallest benefit.

On the eve of the 1978 Revolution, the world Bank noted "In few countries is the health situation as serious as in Afghanistan. Disease and 111 ness are rampant, and the infant mortality rate is no of the highest in the world." Literacy rates in Afghanistan ned low (11-128), with only an estimated $1 \%$ of rural women : ate. Nearly $70 \%$ of all schools lacked proper buildings (Seven year Plan), and urban schools often operated on double shifts.

\section{FROY REVOLUTION TO REBELIION}

The revolution of April 27, 1978 was complete in two days, with fighting largely limited to opposing factions of the military. Within days the new Government issued its Basic Lines of Revolutionary Duties of Government of Democratic Afghanistan, calling for basic social reforms in Afghan society. These reform programmes included equitable distribution of land; abolition of usurious land-related debt and of bribe prices; and a massive literaci campaign; especially for women. 
Implementation of the reforms, the conflict of lideology with tradition, the use of coerclve state power, and the violent divisions between the Khalqi and Parchami factions of the ruling Peoples Democratic Party of Afghanistan (PDPA) precipitated and fed a rebelilion, and the counter rebelilon destruction, which have devastated the country.

Whatever the fustice of the intended PDPA reforms, it was largely lost in their implementation. Though Government could redistribute land and abolish usurious debt, it could not create overnight a new credit structure in the rural areas. The Agricultural Development Bank in 1978 reached only 7\% of farmers. Once landless peasants might now receive land, but they had no landlord to give them seeds, fertilizer, or tools required to continue the agricultural cycle. Abolition of bride price, while attractive to urban youth, threatened an institution still important in rural areas and which gave women some security in a male dominated world. Forcible education for women struck at the heart of deeply held beliefs about women. Hasty and mismanaged reform, when combined with Khalgi Government arrests, imprisonment, torture and execution of enemies, including members of the once allied parchami faction, were midwives to the Afghan war.

\subsection{PRINCIPAL EVENTS OF THE WAR}

Armed rebellion grew slowly. By March of 1979, for example, rebellion in Kunar Province made UN operations no longer viable. In May of 1979 a major uprising threatened Government control of Herat and was put down at a heavy cust of human life (estimated at $5-25,000)$. Population flight, to urban centres and abroad, began
as early as 1978 .

Elimination of the Parchami faction from Government did not end tension within the ruling Khalqi group. In september of 1979, President Taraki was. replaced by Hafizuliah Amin following an incident which cost Taraki his Iife. The growing rebelilion and the capacity of the Amin Government to control it doomed Amin's tenure. By December of 1979 soviet troops intervened in Afghanistan to play a more active role in quelling the rebelition and assuring the stability of the PDPA Government. Haflzullah Amin was killed and Babrak Karmal, head of the Parchami faction, returned from abroad to take control of Government. The soviet intervention not only assured the capacity of the PDPA Government to survive, but it introduced a new level of technology or capacity for destruction.

The outside introduction of massive high technology raised the stakes in the rebelilon. The preponderance of capacity to destroy rested with the Kabul Government. Bombs, fet aircraft, mines Including anti-personnel devices, and helicopter gunships were among the instruments available. over time and with the support of U.S., Arab, Chinese and other donors, the mujahidin acquited 
technology more effectively to resist the Government. For the purposes of this analysis, however, what is important is the destructive capacity avallable to all parties, permitting a level of destruction quite new to the Afghan experience.

\subsection{THE ACCORDB}

The Accords concluded in May of 1988 laid the groundwork for the withdrawal of Soviet troops from Afghanistan. Though withdrawal was completed by February of 1989, the Accords have not enabled a political settlement acceptable to a critical mass of Afghans. Nor have they produced an end to the fighting which continues between the Government and the mujahidin, and among the mujahidin. For the present there is a situation of political irresolution, and few clear signs of how resolution will emerge.

\subsection{CURRENT BITUATION}

Dr. Najlbullah, who replaced Babrak Karmal in 1986, heads the amnesty and welcoming New policies of reconcliliation include prisoners; and an back of mujahidin; release of political in public pronoucements. assistance earmarked for The Government has agreed to allow UN its control through cross below). The power of the border operations from Pakistan (see to the major urban centres Government is effectively limited surrounding areas, especially (Kabul, Mazar-1-Sharif, Herat and in Kabul controlled areas is about North). The total population the total area.

The seven principal parties of the mujahidin resistance based in Pakistan created a 14 member cabinet in July of 1988 to head an Afghan Interim Government. The Pakistan based party leaders are with one exception not traditional leaders but heads of followings held together by traditional or fundamentalist political ideas. Several of the leaders had come to Peshawar prior to the 1978 revolution, in opposition to the previous Daoud Government.

Mujahidin forces have increased their control inside Afghanistah, taking over several small towns (eg. Barikot and Assadabad in Kunar): They have failed to date in the costly effort to take Moreover, fighting has erupted route from Kabul to Pakistan. significantly the Jamiat-i-I between mujahidin groups, most the latter of which, headedslami and the Hezb-I-Islami parties, the largest share of western by Gulbuddin Hekmatyar, has received

Regional Commanders are another critical element in the political strength. The reglonal bases of the commanders vary in size and 
traditional leadership, but more likely they emerged as natural military leaders. Several of the commanders have developed a civilian government structure, providing basic services and raising taxes. Several commanders are said to have negotiated ceasefites or autonomy from the kabul Government.

Flux, uncertainty and fragmentation are likely to be the characteristics of the Afghan political situation for the foreseeable future. Planning for the critical immediate and intermediate needs of children and women will have to take place within this uncertain environment.

\subsection{CONBEOUENCES OF TAR}

If Afghanistan was poor prior to 1978, the impact of warfare has destroyed the nation's resource base for survival and development. The sections following will detail some of the specific costs of war to Afghanistan, and to specific groups of Afghans. The destruction has differential impacts by region of the country and extends to the following areas:

- Human resources, through loss of life or emigration;

- Infrastructure, especially transport, schools, health facilities;

- Social cohesion, commitment to a civil society.

Measuring the geography of destruction is inexact. sliwinski suggests that destruction was greatest in the central Northern border provinces, and in the pakistan border provinces.

Rebellion and war since 1978 have produced 1 to 1.5 million dead on both sides and substantial numbers of children and adults disabled. Perhaps as many as $20 \%$ of Afghan women have been widowed; at least half a million children orphaned. Seven to eight million Afghans have been uprooted from their homes. More than a quarter live as refugees outside the country. Perhaps $50 \%$ of Afghanistan's villages have been destroyed. An estimated $25 \%$ of paved roads and $33 \%$ of secondary roads plus 300 bridges have been damaged or destroyed. Basic services have broken down.

More serious, the elements of social cohesion, which enable a people to work together for national development, have broken down in Afghanistan. Ideology has polarized national dialogue. Education is perceived by some as a vehlcle of forelgn propagahda rather than an ingredient of national development. The role of Government has become suspect among large segments of the population. Leadership is fragmented. The instruments of state power have been weakened, and competing bureaucracies in Kabui, in rural areas, and among refugee partles, have emerged. 


\section{PART II - DEMOGRAPAY}

\subsection{OVERVIET}

The demographic profile of Afghaniṣtan is unique in today's world: - it is the only country showing a decline in the popluation in
the past decade;

$1 / 4$ to $1 / 3$ of its population are refugees, the majority
originating from rural areas;

- up to 98 of the population may have been killed; - between 1 and 2 million people are internally displaced,
depopulating rural areas for safe havens in the cities;

- there is evidence of an extremely high dependency ratio; - total fertility rates are among the highest in the world,
exceeding 13 for some groups. (from Hobbs and sliwinski)

The unusual Afghan demographic profile influences the current situation of children and women, and limits the opportunities for improving that status. Demographics are an overarching variable, influencing sectoral analysis. This section looks at what is known about the Afghan population from 1972-73 to the present, examining particularly issues such as age structure, vulnerable groups, Where possible and and the potential for population growth. location/status (urban, rural, region data is presented by gender, age, ethnicity. Final region, nomad, refugee, displaced) implications for the situation

Reliable data on the Afghan population is scarce. The only rebellion and reached only an $(1979)$ was hampered by the growing The following sources are used imated 55-60\% of the population. consistency or variations in estimates available: trends and the

- The Afghan Demographic Survey (ADS) was conducted in 1972-73 with technical support from the State University of New York.
overall population figures were not accepted by the
Government, but the mortat Government, but the mortality, growth and other rates were generally incorporated into statistics.

- "Afghanistan: A Demographic Profile", Frank B. Hobbs of the 1988. 
- "Afghanistan: The Decimation of a People", Marek sliwinski, 1988. This analyses and estimates current Afghan population patterns, building on previous population data and the results of a 1987 survey in 318 refugee camps in Pakistan. The difficulty of using sliwinski's estimates is that they ate expressed as percentages. Sliwinski indicates that his "survey assumes that. the Afghan population remained roughly static during the war, with births equaling deaths", but a full explanation of assumptions is not available in his article.

Reference is also made to the data in the first seven year Economic and social Development Plan (1355-1361) as well as Publication No. 5 of the Central statistics office, Estimates of the Population of Afghanistan in 1357 . statistics of the Daoud These documents represent the official Government in 1978 .

\subsection{POPULATION DATA}

Distinction must be made between estimates of the population of Afghanistan, and of the population of Afghans, the latter of which would include those with some likelihood of returning to Afghanistan. Estimates suggest a significant population decline inside Afghanistan, an increase in overall population of Afghans despite heavy war casualties, massive internal and external dislocation of population, and a paucity of data on the nomadic
population. 
2.1 Comparing Estimates

The U.S. Census Bureau (Hobbs) estimate of the 1988 population inside A $g$ han is tan $(14,184,000)$ is extrapolated from the 1979 Census figure. silwinsk1, as noted, develops his estimates on the basis of the 1979 Census figure of a total population of 15.5 million. The ADS population may have been an underestimate because of the sampling frame used. Likewise, political factors are thought to have expanded the Government estimates of the 1975 populations.

The data in Table 1 , despite its limitations, offers the most practical starting point.
TABLE 1 - Afghanistan

Comparative Population Estimates:

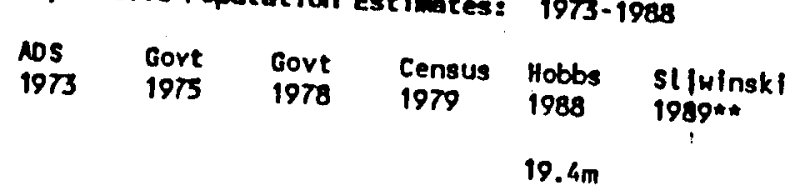

Total Afghan

Population

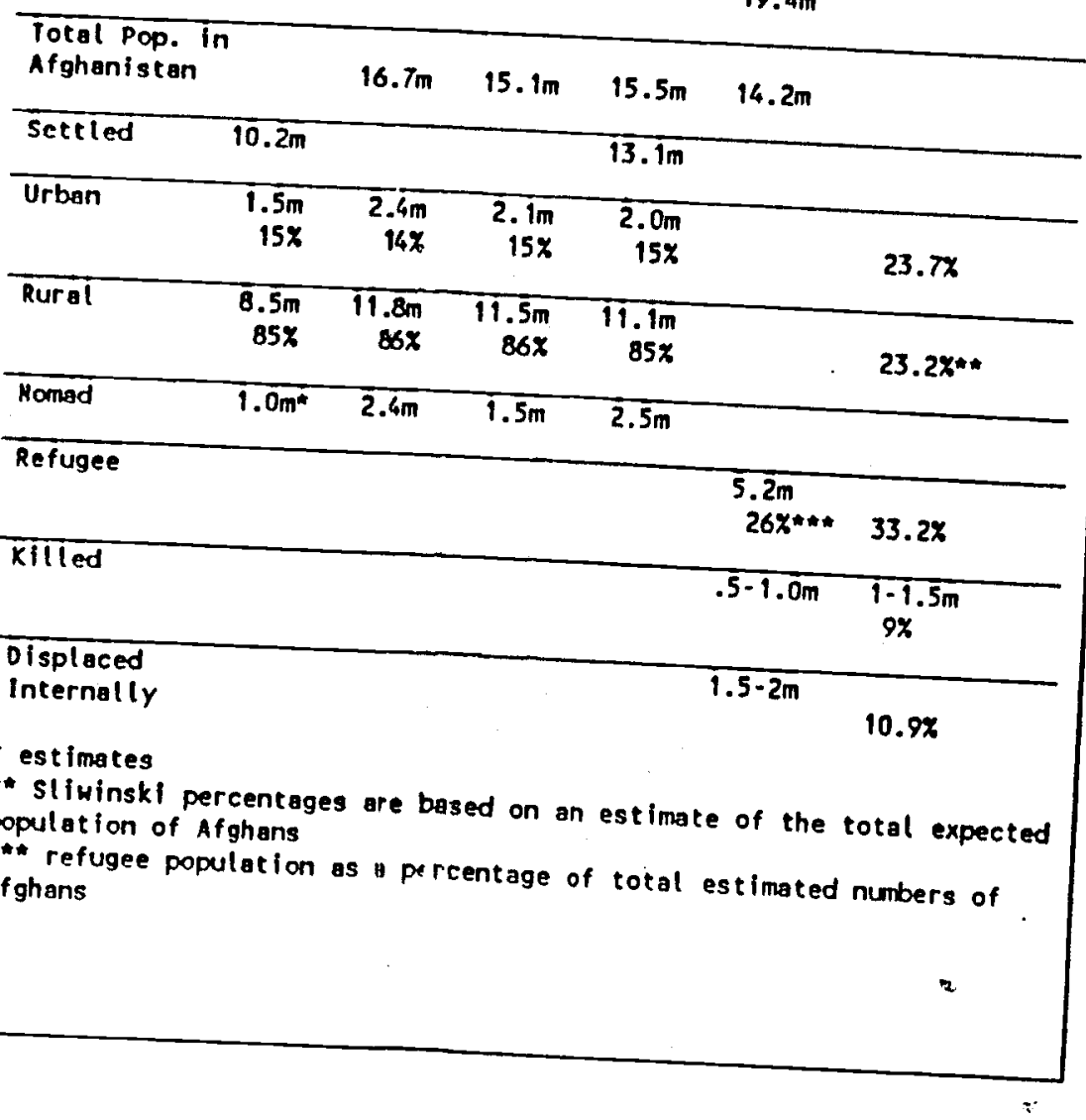

\section{2-2 Population Totals}

The U.S. Bureau population estimates, while recognizing their of current population insidechnical estimate available to date population was 14.2 million. From 1979 tan. The 1988 estimated negative growth (see Figure 1). This cor 1982, the population saw the peak years of refugee outfiow This corresponds to other data on the population is expected to reach issyling no return of refugees, 
FIGURE 1 - Total Midyear Population

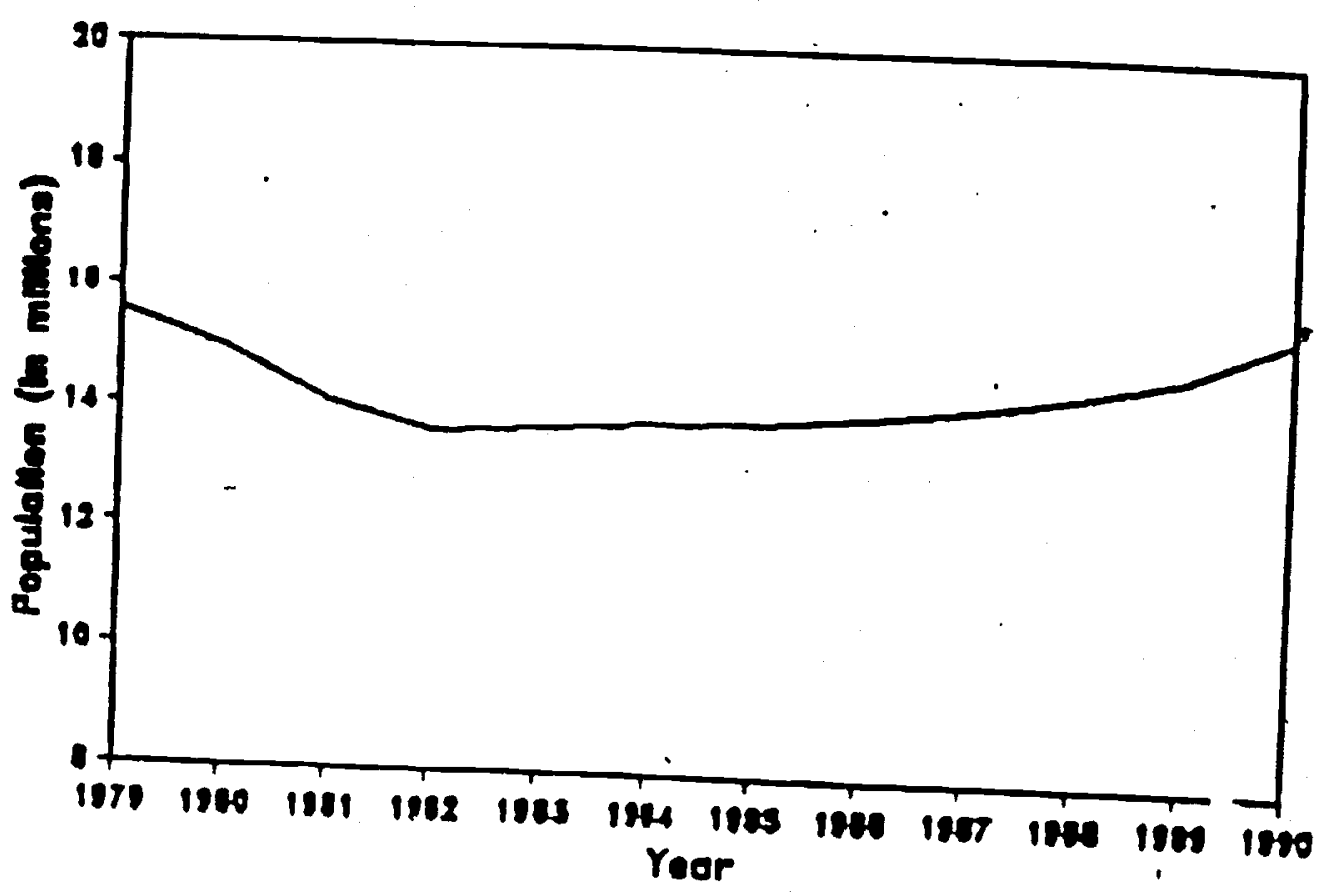

Source: Hobbs 1988

\subsection{Casualtieg}

Estimates of the number of people killed are only estimates. All suggest a high level of mortality. sliwinski, projecting from or 98 of the population had been kilied suggests that 1.25 million are lower. What is significant for the (1987). Other estimates total number, assuming it to be for the future is not only the Using sliwinski's analysis as indicative, but the distribution. appears that war related deaths are among men, and heaviest in the principal not surprisingly, highest The difference is 38 war related deaths, productive middle years. per thousand for men. This is reflect thousand women, but 134 widows and orphans and in the high dependen in the high number of sliwinski suggests that $20 \%$ of refugendency ratios (see below). war; a UNICEF Afghan Women's Skill women identified themselves as vidows inventory found that 18.68 of number of orphans, but sliwinst' among one sample suggests that there and probably more than a million. child who has lost the father].

Female mortality from bombing is estimated at nearly twice that of
males. 


\subsection{Internal D1splacement}

Little is known about internally displaced population, except that it is large ( 1.5 to 2 million) and that displacement has taken the form of migration to the several cities perceived as havens, or to
the more remote interior.

Urban populations are estimated to have increased from 15\% (1979) to $23 \%$ (1989) of population. Kabul increased from 900,000 to more than 2 million during that period. Mazar-i-sharif, relatively The largest portion of migrants, also saw significant increases. and children, contributing to the the cities appear to be women cities ill-equipped under war the poor, dependent population in expand basic services. This conditions to maintain let alone (below) for Kabul. Evidence in may be reflected in health data Kabul of perhaps 40,000 per monte 1989 suggested an exodus from of increased bombing as well other cities, heavily exposed increasing shortages of food. Kandahar, and most recentlyosed to bombing or warfare, Herat,

There is evidence of considerable rural to rural migration, as frequently away from plains areas locations sought security, in Annex II suggests the areas to and into the mountains. Map $A$ needs to be known about land use which displacees have gone. More people for return.

\subsection{Outmigration}

Refugee outmigration is one of the most visible aspects of the Afghan demographic profile. Roughly $33 \%$ of the 1979 Afghanistan
population, or $26 \%$ of the present Afghan population, have left the
country. The U.S. Census Bureau angly a total of 5.2 milition refugees. to $3.5 \mathrm{milli}$ on may be in Pakistan Various sources estimate that 2.5 is sparse on the nature of migration 1 to 2 million in Iran. Data avaliable which indicate the saliont tran; several studies are Pakistan.

\section{a. Peak Migration - 1979 and 1980}

Refugee arrivals peaked between 1978 and 1980, but sibstantial numbers have continued to arrive each year since. 
FIGURE 2 - Year of Leaving Afghanistan (Refugees in Pakistan)

Source:

Christiansen

(UNRISD 1987)

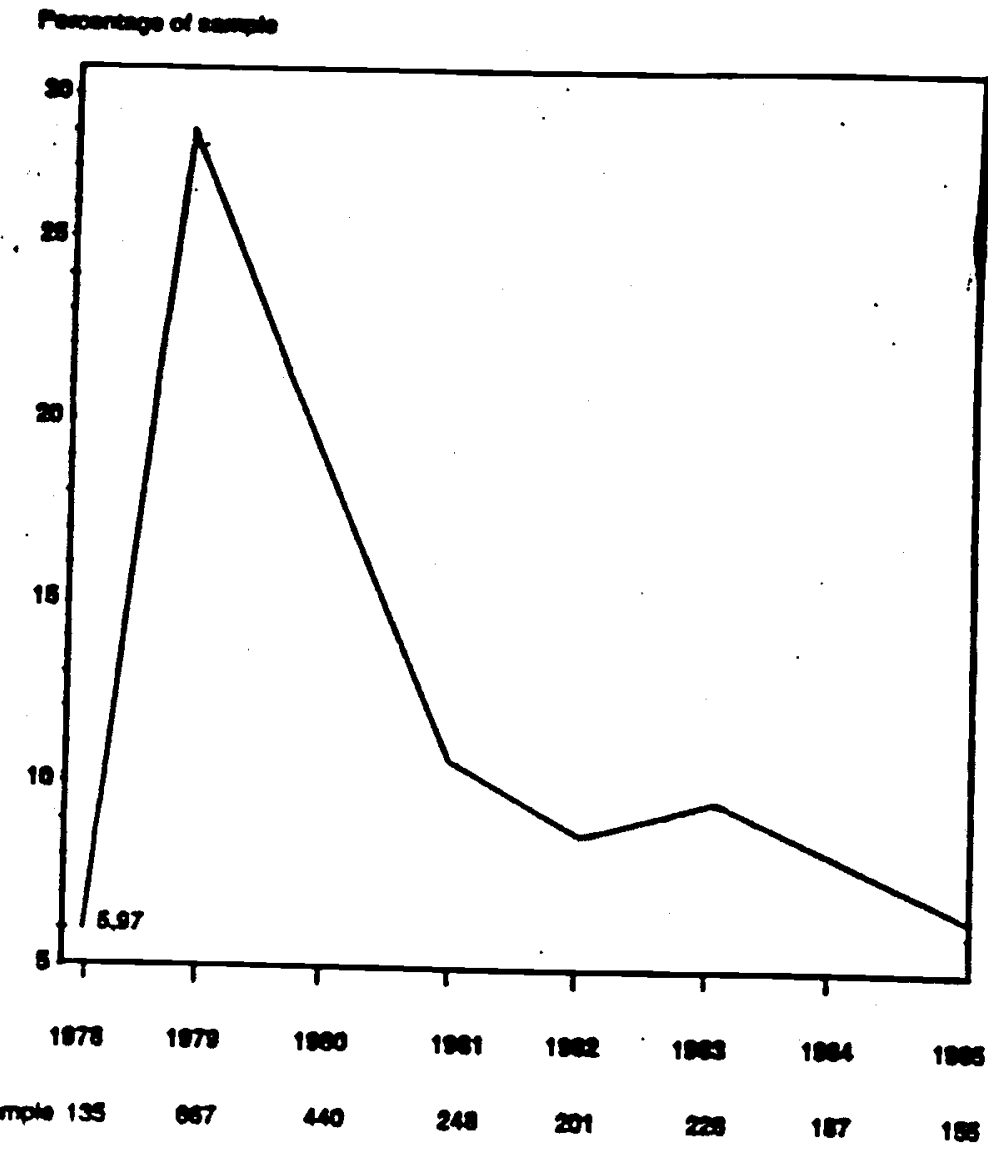

The long length of the refugee experience for a substantial portion of the population, including children born outside their homeland, has implications for repatriation.

b. Differentiation by place of origin

Little data is available on the place of origin of refugees in Iran. Logic suggests that refugees in Iran originate in border provinces, or shilite populations in the central provinces.

Three estimates of the place of origin of refugees in Pakistan suggest that over $62 \%$ come from the provinces bordering pakistan, plus Logar. The survey work analyzed by sliwinski suggests that a next major portion come from a few Northern provinces, notably Kunduz, Baghlan and Balkh. Sliwinski's analysis also suggests the virtual depopulation of certain Pakistan border provinces (Kunar, Paktia, Zabul and Kandahar) with substantial depopulation in others (Kunduz and Baghlan in the North, and Paktika and Logar on the Pakistan border). Observations of the Salam Missions confirm to some extent the reality of depopulation. Salam $v$ in Kunar Provinces (December 1988) noted that only a small fraction of the civilian population remained, mostly along the banks of the Pech River. 
TABLE 2 - Province of Origin: Afghan Refugees In Pakistan

\begin{tabular}{|c|c|c|c|c|}
\hline \multicolumn{3}{|c|}{ st iwinski } & \multirow{2}{*}{$\begin{array}{l}\text { UNRISD } \\
\text { Refugee } \\
\text { Pop. by } \\
\text { Origin } \\
1986 \text { - X }\end{array}$} & UNHCR \\
\hline $\begin{array}{l}\text { Province } \\
\text { Pop. In } \\
\text { Afghanistan } \\
1979-x\end{array}$ & $\begin{array}{l}\text { Refugee } \\
\text { Pop, by } \\
\text { Origin } \\
1987-x\end{array}$ & $\begin{array}{l}\text { Province } \\
\text { Pop. } \\
\text { living in } \\
\text { Pakistan }\end{array}$ & & $\begin{array}{l}\text { Refugee } \\
\text { Pop. by origin } \\
\text { (Pakistan/1ran) } \\
\text { 1988 - } x\end{array}$ \\
\hline
\end{tabular}

\begin{tabular}{|c|c|c|c|c|c|}
\hline $\begin{array}{l}\text { Ghazni } \\
\text { Helmand } \\
\text { Kunar } \\
\text { Nangahar } \\
\text { Pakt la } \\
\text { Pakt Ika } \\
\text { Kandahar } \\
\text { Yabul }\end{array}$ & $\begin{array}{l}4.6 \\
3.7 \\
1.8 \\
5.3 \\
3.5 \\
1.7 \\
4.0 \\
1.3\end{array}$ & $\begin{array}{r}5.6 \\
4.5 \\
8.0 \\
6.7 \\
14.4 \\
2.8 \\
10.3 \\
4.4\end{array}$ & $\begin{array}{l}30.0 \\
30.0 \\
90.0+ \\
32.0 \\
90.0+ \\
53.0 \\
65.0 \\
85.0\end{array}$ & $\begin{array}{c}1.4 \\
5.4 \\
12.8 \\
8.4 \\
16.4 \\
9.7 \\
2.4\end{array}$ & $\begin{array}{r}9.6 \\
4.1 \\
5.9 \\
10.5 \\
9.2 \\
7.0 \\
12.3 \\
1.3\end{array}$ \\
\hline
\end{tabular}

Total

MORTHERH BORDER

Badakhshan

Badghis

Baghlan

Balkh

Faryab

Joz Jan

Kunduz

Semengen

Takhar

Total

IRAN BOROER

Farah

Herat

Nimroz

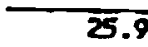

25.9

3.5

1.6

3.5

4.8

4.1

4.2

3.9

1.9

3.7

56.7

60.0

$\begin{array}{rr}Y & \gamma \\ \gamma & \gamma \\ 7.6 & 51.0 \\ 5.7 & 30.0 \\ \gamma & \gamma \\ 1.5 & 10.0 \\ 9.2 & 59.0 \\ 1.7 & 22.0 \\ \gamma & \gamma\end{array}$

$r$

51.0

30.0

10.0

59.0

$r$

25.7

20.0

$\begin{array}{ll}\gamma & y \\ \gamma & \gamma \\ \gamma & y\end{array}$

$Y$
$Y$
$Y$

0.0

0.0

0.1

$r$
$\gamma$

2.6
0.5

0.0

0.0

2.9

0.3

59.9

Total

CEMTRAL hIGHLANOS

Bamiyan

Ghor

Uruzgan

Total

KABUL REGION

Kabul

Kaplsa

Laghman

Logar

Parwan

Wardak

Total

Total

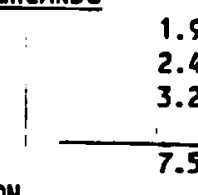

7.9

$\gamma$

1.9 Y $Y$

2.4

3.2

$Y$
$Y$
$Y$

$\gamma$

$\gamma$

0.1

0.2

0.8

1.0

9.3

0.1

2.9

8.4

1.5

0.8

20.9

0.7

1.1

2.7

0.3

na

0.2

2.0

0.4

0.1

13.3

2.1

1.8

5.4

2.7

3.4

$\gamma$

6.1

9.0

100.0

27.0

- Probably combines data from Paktika

sources: stiwinski 1989; UNRISO 1988; UNHCR 1988 
Methodological questions as well as some significant inconsistencies in estimates make the data in general a weak base for planning. While this data may not be adequate for planning activities, it does assist identification of target groups and of issues for programme development.

The largest group of refugees, all data suggest, originated in the Pakistan border areas where access was relatively easy. Some of the border provinces appear to have been largely depopulated. Thus the total potential population of the border provinces includes a majority (nearly 60\%) who share not only their Pashtoon background, but the experience of Pakistan refugee life.

The Northern border areas represent a separate group. The data appear contradictory of the percentage of Northerners in the (Pakistan) refugee population. One explanation, suggested by other observers, may be that refugees from the North came largely from Pashtoon families who had settled in the North in the past century. This is corroborated by estimates of pashtoons in the Pakistan refugee population which range from $70 \%$ (UNRISD) to $85 \%$ (Sliwinski). Both suggest that the proportion of Tajiks and Uzbeks, principal northern groups, in pakistan is less that 10\%. If this hypothesis is true, the question of whether and where the Pashtoon refugees will return, as well as related questions of land and resources, will need to be answered. Return of refugees to rural areas may create a land scarcity, decreased demand for tenants, and a fall in wages (cf. Roy 1989).

Little is known about refugees in Iran, though they have come particularly from the border provinces and, to a degree less than their proportion in the 1979 population, from the central Highlands (Hazarajat). Both of these areas are Farsi (Persian) speaking and include most of Afghanistan's Shi'a population, factors enabling easy migration to Iran. The Balouchi population in the southwest have largely gone to the Balouchi areas in Iran.

Heaviest emigration from the Kabul Region is from Logar and Laghman, both contiguous with border provinces, and both predominantly Pashtoon areas.

Emigration from other Regions appears to have been negligible.

Data also suggests that the bull of the refugees are rural agriculturists, $70 \%$ or more, with few other skills.

\subsection{Nomads}

Nomads as a group seemed to have lost their identity as a group in the analysis of the Afghan situation during the past decaded 
Nomads (Kochis) had a traditional pattern of summer grazing in the mountains and winter in the warmer lowlands, including in Pakistan and Iran (See Map in Annex). It is not clear to what extent who are Durrani or Ghtl been hampered, and the nomad's, many of in refugee numbers.

3.0 GENDER DIFFERENTIATIONB

striking gender distinctions in the Afghan demographic proftle have implications for programming. A longstand $1 \mathrm{ng}$ distinction and primary indicator of the impact of the status of women are the data on sex ratios and life expectancies.

The significant excess of males over females is demographically unusual and is normally an indicator of the low status of women and their lack of access to and control over basic needs. Heavier war-related mortality among men may have Sources: Afghan Demographic Survey (Vol IV): 1979 Census:
Hobbs (US Census Bureau)

\section{FERTIIITY AND POTENTIAL FOR POPULATION GROWTH}

Hidden behind the recent decrease in population inside Afghanistan lies potential for rapid population growth. The 1979 Census Indicates a Total Fertility Rate for the country of 7.08 , with urban women bearing an average of 5.8 children, and rural women an average of 7.3 . The fertility rate is exceeded by that of few $2.5 \%$ in the 1970 's. population growth rate was estimated at $2.3-$ Afghanistan. When some $1980^{\prime}$ s saw negative growth inside repatriation beyins, the measure of stablilty returns and Afghanistan's fertility rate population growth rate will rise. and even using assumptions of has shown only a slow rate of decline, population of the country is moderate fertility decline, the total 20 years. The projections deveojected to double within the next Tabie 4 below) suggest the scale of by the UN Census Bureau (see possible for Afghanistan under of population growth which is 
rates and return of refugees.

Small scale surveys in refugee camps and across the border in rural areas suggest, however, that the fertility rate may be increasing in the short run. A survey in camps between Hangu and Thal in Pakistan suggested a possible total marital fertility rate of 13.6 live births during child bearing years.

Fertility and growth are population variables with potential to be a major constraint on development efforts in the intermediate term.

\subsection{AGE BTRUCTORE AND DEPENDENCY}

TARE 4 - Population Projections Afghenistan to 2010 Under hasuptions of Mediun Fertflity and Variable Patterns of Refugee Return (000s)

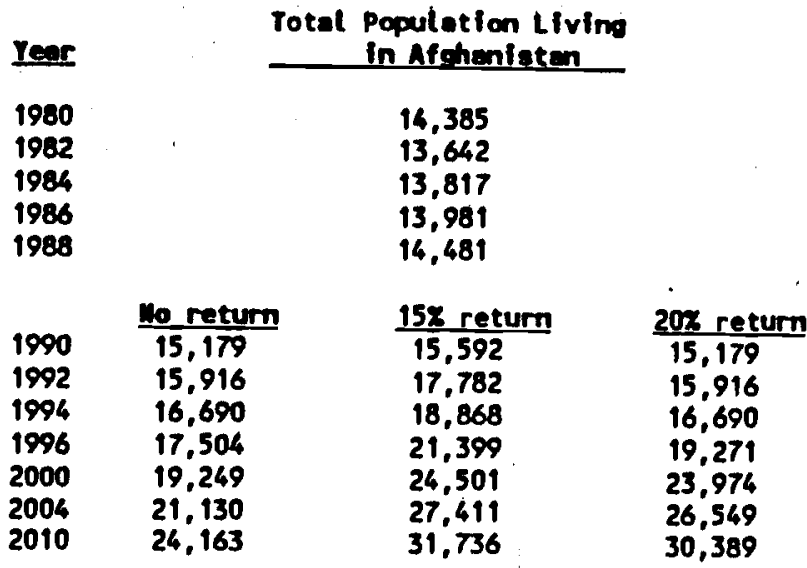

Notes: No return assumes refugees in Pokistan and Iran do not return. $15 \%$ return assumes that the Afghen population in Pakistan and Iran begin to return to Afghanistan in 1990 with 15\% of those outside returning each year to 2010. 20\% return assumes that the Afghan refugee population in Pakistan and Iran begin to return in 1995 with $20 \%$ of the refugees outside returning each year until 2010.

Source: U.S. Bureau of the Census (Hobbs) 1988
In 1975, an estimated (CSO) 43.28 of the population was 14 years and under; the figure in 1979 was $44 \%$.

Data is not available on a national scale for age structure for the period after 1979, but survey evidence suggests that the population below 15 continues to grow, albeit with enormous varlations by population location. . Reports from cross border medical operations as well as those of salam missions suggest that in areas heavily affected by migration. the numbers of children, as well as of older people, have declined. One EPI progress report from Ghazni, for example; notes that children under 5 represented only about $10 \%$ of the population,
TABLE 5 - Age structure Afghanistan 1354 (1975)

\begin{tabular}{lrr} 
Ane Groge & $1354(000)$ & $\begin{array}{r}\text { X of Total } \\
\text { Population }\end{array}$ \\
\cline { 2 - 3 } Total Population & 16,605 & 100.0 \\
$0-4$ & 3,066 & 18.4 \\
$5-9$ & 2,209 & 13.2 \\
$10-14$ & 1,934 & 11.6 \\
$15-19$ & 1,694 & 10.1 \\
$20-59$ & 7,024 & 42.1 \\
$60+$ & 738 & 4.4
\end{tabular}

Source: Central statistles office, Serial No.10, Estimation of the Population of the Country During the Vears 1348-1354, 1355-1361 
against the pre-war national ratio of 18.48 . In the refugee camps in Pakistan, there is evidence of a growing percentage of children under 15 and of older men and women (UNRISD) and of a growing birth survey data surplus of males two districts show a contrary situation, with a in Kabul is not avail all age groups (WHO 1988). Statistical data Evidence suggests 44 ) largely for war related reasons proportion of adult males (15proportion of females in the increases in the proportion of young age category along with burden of dependency presumably oung and older populations. This income groups and groups which have falls hardest on women in lower migrated to Kabul to avold the in the population of Kabul While the total increase population at risk because of since 1979 (and therefore of the to nearly two thirds of the increased dependency ratios) amounts migrants to the capital.

In summary, there would appear to be high dependency ratios among the Pakistan refugee populations and probably among recent migrants
to Kabul and other cities controlled by the Kabul Government. The
impact of impact of high dependency ratios on possible return and resettlement efforts is a critical factor in planning in future

-O THE DEMOGRAPHIC PROFILE AND PLANNING FOR CHILDREN AND WOMEN

The unusual demographic profile of Afghans suggests a framework for analysing the situation of children and women.

\section{Target Groups}

There are several inter-locking layers of categories among the Afghans which help identify groups most at risk:

Vulnerability Factors

Family status

- class/income

- widows, female heads of households

- orphans

War Impact

- disabilities

- trauma

- loss of resources

- security

Invisibility of groups (internal refugees) nomads)

- lack of information

- Inaccesibility to outside interventions 


\section{Location Factors}

Kabul Government controlled areas (largely urban)

Refugees

Internal Refugees

Rural Residents
- Iran

- Pakistan

- by place of orlgin

- potential for return

- to urban areas

- to rural areas

- potential for return

- low war impact

- high war Impact

Nomads

\subsection{Gender Differentials}

Gender differentials are characteristic of the Afghan demographic profile and, as will be seen, of the situation of children. Differentials like the unusual sex ratio, showing an excess of men over women, as well as the lower life expectancles for women, are standard indicators of low status and poor health of women in society. Gender, therefore, is a basic consideration in planning for children in the immediate future and the longer term. While Afghan data in the past has had some Iimited gender disaggregation, international donors in general have not placed priority on gender disaggregation in data analysis and planning, leaving the impact of gender differences little explored.

\subsection{Potential for Population Growth}

Population growth is neither a survival nor an immediate issue in the Afghan context, particularly as mortality from warfare continues. Because of the potential impact of explosive population growth inside Afghanistan on efforts to address the situation of children and women, however, population growth as an important factor needs to be identified at the earliest planning stages. 
PART III - BITUATION OF AFGHAN CHILDREN AND TOMEN - HEALTH

\subsection{MORTALITY}

\subsection{Infant Mortality Rates}

While the validity of the figures in Table 6 cannot be readily analysed, they all indicate levels of mortality higher than most countries in the world and they suggest some differentials and trends :

- Rural infant mortality continues to be higher than urban rates, and is probably higher in 1989 than prior to the outbreak of fighting.

- Urban mortality rates, using Kabul as the indicator, may have increased in the same period, perhaps reflecting the impact of the near tripling of Kabul population in a ten year wartime period.

- Refugees in the Northwest Frontier Province of experienced a dramatic drop in infant morality consequence of proximity to the bilateral and

1979 Census $\quad 185.0$

- Oaen 241.0
Maternal per/100,600

MATIONAL

1973 ADS"

- adjusted

- unadjusted

213.9

$184.9 \quad 208.2 \quad 160.8$

640

KABUL

MOPH/WHO

1972-1975 survey $116.6 \quad 106.4 \quad 125.4$

1989 (Pigot) $\quad 135.8$

REFUGEES IN IRAN

1988 WHO/Rezai

- Birjand $\quad 176.0$

778

REFUGEES IN PAKISTAN

1985 - CDC*

- All

- MUFP

119.0

Baluchistan 106.0

1989 UNICEF

- NUFP

81.0

RURAL AFGHANISTAN

$\begin{array}{lllll}1973 & \text { AOS Adjusted } & 19 \overline{3} .2 & 216.7 & 169.2\end{array}$

1984 MSF Surver*

- Hazarajat and

Bedakhshan

284.0

$400+$ * Reported in UWICEF Statistical Profile of Children and Mothers in
Afghanlstan 1977 .

- Reported In UNHCR, Progress Report on EPI Programe for Afghan the bilateral and NGO , perhaps a Pakisan Government services. Because of the magnitud and the change between the CDC Survey in 1985 of the magnitude of the report in 1989, ---a drop from $106 / 1000$ and the UNICEF Peshawar area where further research discover causes of change. - Refugees in Baluchistan

experience high infant mortality. 
The 1972-1975 Ministry of Public Health/wHo survey of Infant and Early Childhood Mortality in Relation to Fertility patterns breaks down mortality rates by age group of the mother, by gender of the child and by neighborhood. Their findings pointed to significantly higher mortality rates for females, for residents of crowded and poor areas, as well as for children of mothers under 20 years of age.

Infant Morality Rates in neighboring Moslem countries are Pakistan, $115 / 1000$ and Bangladesh 123/1000 (1985). Both Pakistan and Bangladesh have experienced a decrease of more than 30 points in the IMRs in the 20 preceding years.

\subsection{Child Mortality Rates}

There is less data available on childhood or under five mortality rates. The 1979 Census estimate of 304 per thousand remains a high figure. The MOPH/WHO survey in Kabul indicated that the second Year of life $(1-2)$ saw the highest death rate after infancy and
before old age.

\subsection{Maternal Mortality Rates}

Likewise, there is little data on maternal mortality rates. The 1970 's estimate $(640$ per 100,000$)$ is one of the highest in the world, and recent survey estimates suggest that it is even higher for identifiable groups, particularly women isolated in rural Afghanistan or in one of two refugee districts surveyed in Iran.

\subsection{Causes of Mortality}

For all groups of the population, the principal causes of mortality are preventable by immunisation or by improved health, hygiene and

\subsubsection{Neonatal and Infant Mortality}

Among neonates, a principal cause of death is tetanus. In 10 refugee camps in NWFP a survey found a neonatal tetanus rate of $13 / 1000$. In two refugee districts surveyed in Iran the neonatal tetanus rates were 64.5 and 155 per 1000 births. The immediate explanations are the lack of access for women of child bearing age to tetanus immunisation as well as the unsanitary conditions of delivery for most Afghan women. sterile instruments for cutting the cord and items Iike soap and water are frequently absent. Unsanitary delivery is a consequence first of the lack of knowledge of Afghan women themselves and the low status of the birthing
process and of traditional birth attendants (Dais). Second, Afghan
women have little access to modern denters women have little access to modern delivery services, not only 
because of cultural limitation, but also because of the absence of
such facilities.

A contributing cause of infant mortality may be high incidence of low birth weights, particularly among populations where female 1989) suggest a rate of Low Birth Weight of

\subsubsection{Onder Five Nortality}

Diarrhoea, acute respiratory infections, and measles, particularly when compounded by malnutrition, probably account for $50 \%$ or more of infant and childhood mortality. While there may be differences by location, the principal causes of death have remained unchanged over time. Data is $11 \mathrm{mited}$ to statistics of curative facilities or to surveys based on recall. In 1978 a UNICEF consultant provided the following summary of data on causes of mortality (Table 7).

Data on the causes of infant and child mortality in the 1980's is more scanty and less amenable to direct comparison than that of the 1970's. Nonetheless, formal and informai survey results all pinpoint diarrhoea, acute respiratory infections and vacclne preventable diseases, in most cases compounded by malnutrition, as the principal causes of under five mortality.

\section{Refugees}

Pakistan - A survey conducted by the Center for Communicable following causes of under UNHCR in 1984 and 1985 identified the

\begin{tabular}{|c|c|c|}
\hline Location & $\begin{array}{l}X \text { of deaths due to } \\
\text { respiratory infections: } \\
\text { diarmoea, winutrition, } \\
\text { and eneasles (age range) }\end{array}$ & Source \\
\hline Kabul * & $\begin{array}{l}51 x(0-1) \\
84 x(1-4)\end{array}$ & MOPH/WHO 19 \\
\hline Kabul * & $68 x(0-14)$ & UNICEF 1977 \\
\hline Hazarajat * & $57 x(0-5)$ & Wakeham 1974 \\
\hline $\begin{array}{l}\text { Baghlan, Ghazni, } \\
\text { Helmand Provinces }\end{array}$ & $\begin{array}{l}40 \%(a l l \text { ages }) \\
36 x(0-5)\end{array}$ & MSH 1977 \\
\hline Jawz jan Province & $54 x(0-20)$ & CINAM (UNICEF) \\
\hline $\begin{array}{l}\text { Parwan Kapisa } \\
\text { Provinces }\end{array}$ & $\begin{array}{l}68 \%(\text { all ages }) \\
73 \%(0-5) \\
68 \%(0-5)\end{array}$ & MSH 1975 \\
\hline Cabul * & $62 x(0-5)$ & $\begin{array}{l}\text { Srivastava, et } \\
\text { n.d. }\end{array}$ \\
\hline $\begin{array}{l}\text { re all ef ther anal } \\
\text { acilitfes (UNICEF } \\
\text { rlvastava n.d.) or } \\
\text { MOPH/WHO 1978, MSH } 1\end{array}$ & $\begin{array}{l}\text { essed that none of these fi } \\
\text { study of heal th in the com } \\
\text { ysis of diseases reported } \\
1977 \text {; Wakeham 1974; } \\
\text { they are information obtain } \\
\text { i975, 1977, CINAM 1973). St }\end{array}$ & $\begin{array}{l}\text { Igures derive } \\
\text { munity. They } \\
\text { to curative } \\
\text { cINAM } 1973 \text {; } \\
\text { ned by recal } \\
\text { tudies marked }\end{array}$ \\
\hline
\end{tabular}

Source: Feochem 1978

TABLE 7 - Proportion of Nortality due to
Four Major Causes (1970's)

TABLE 7 - Proportion of nortality due to
Four Major Couses (1970's)

$x$ of deaths due to

diarhoea, molnutrition.

$51 \%(0-1)$

978 
Diarrhoea

Measles

Unknown

Malaria with fever

Neonatal tetanus

Malaria with diarrhoea
398

248

218

218

98

38

Malnutrition and acute respiratory infections were not mentioned as causes of death.

Iran - A survey of two refugee districts (WHO/Rezal 1988) identified vaccine preventable diseases including neonatal tetanus, diarrhoeal diseases and acute respiratory infections as acute causes of death.

\section{Rural Afqhanistan}

Estimates of under five mortality in rural Afghanistan, not under the direct control of the kabul Government, come largely from observations of medical teams working in selected areas. Medicins sans Frontieres (MSF), for example, noted that despite the destruction of war in Badakhshan and Nuristan, nearly $80 \%$ of mortality was due to non-traumatic causes. Mortality at apparently increased rates continued, probably according to the diagnoses in Table 7, with increased morbidity and mortality in areas of endemic malaria. The MSF and other medical teams identify malnutrition in combination with infectious diseases as a cause of death.

\section{Rabul Government Areas (Orban)}

In a preliminary assessment of health and nutrition of children in Kabul, Mazat-i-Sharif, and Herat for UNICEF in 1989, Pigot identified diarrhoeal diseases and acute respiratory infections as the two major causes of mortality among hospitalized children. He also noted as relevant the prevalence of vaccine preventable diseases. There is no data available on mortality among under fives due to war related causes.

\subsubsection{Maternal Mortality}

Systematic data on the immediate causes of maternal mortality are scarce, in large part because only a small percentage of deliveries are attended by trained health personnel. In Kabul, which may have the largest proportion of attended births, pigot makes the rough estimate that $25 \%$ of births are hospital or clinic based and therefore attended by health personnel. The remaining deilveries are home based; the percentage of deliveries attended by trained dais may be 15\%. Among Iranian refugees, Rezal indicates that all births were home based, of which $99.5 \%$ were attended by family members and the remaining 0.58 by untrained dais.

Plgot reports on hospital based data in Kabul which identify a high 
rate of complications of childbirth due to placenta retention, delivery complicated hyorrhage, plus osteomalacia which leads to compounded by anemia, poor nutrition and thertality may also be of women (see below).

The lack of prenatal care and screening, the lack of access to food practices, along with the women's own lack of knowledge, and contribute to the unusually high matery conditions of delivery women.

\subsection{MORBIDITY}

An assessment of the causes of morbidity describes the magnitude and range of health problems among Afghan children and women. Not all morbidity may have the severity as discussed above in the development and capacities Morbidity may nonetheless affect the female population.

\subsection{Infant and Child Morbidity}

A comparison of morbidity data from the 1970's period with data available today indicate that morbidity patterns remain similar, with a high proportion of morbidity stemming from preventable
causes, or causes that are simply treated.

\subsubsection{Morbidity in Pre-1978 Afghanistan}

Analysing data from the Institute of Child Health and elsewhere, Feacham notes the seasonality of diarrhoea, with a dramatic rise in incidence in June and a corresponding fall in October. He

finds that $80 \%$ of the children under five seeking treatment for diarrhoea are under the age of two.
TABle 8 - Principal Cacses of Norbidity (by age) sumary of Institutional and Survey Data (1970's)

\begin{tabular}{|c|c|c|c|c|}
\hline Location & $\begin{array}{l}\text { X It lness } \\
\text { Diarrhoea }\end{array}$ & $\begin{array}{l}x \text { Il lness } \\
\text { U: }\end{array}$ & $\begin{array}{l}\text { X Illness } \\
\text { Measles }\end{array}$ & $\begin{array}{l}\text { X Illness } \\
\text { Malnutrition }\end{array}$ \\
\hline
\end{tabular}

$\begin{array}{lllll}\text { Gr. Kabul } & 32(0-1) & 32(0-1) & 7(0-1) & \\ & 41(1-2) & 32(1-2) & 9(1-2) & \\ \text { Kabul } & 33(0-5) & 32(0-5) & 10(0-5) & 4 \\ \text { Kabul } & 47(0-14) & 26(0-14) & 1.5(0-14) & \\ \text { Hazarajat } & 7.5(a l 1) & 17(0-5) & & \\ \text { Baghlan Kapisa } & & & & \\ \quad \text { Helmand } & 13 \text { (all) } & 31 \text { (all) } & 7.5 \text { (all) } & 15-16 \\ \text { Jawz Jan } & 8.7 \text { (all) } & 26(a l l)- & 7.8 \text { (all) } & \\ \text { Parwan Kapisa } & 6.5 \text { (all) } & 14 \text { (all) } & & \end{array}$

URI = Upper Respiratory.Infection Source: Feacham 1978 
other common causes of morbidity identified in the above data Include skin infections, eye infections, parasites, tuberculosis, malaria, DPT, and meningitis (not necessarily in order of magnitude). Hospital data from Kabul in 1973-75 suggest that 258 of admissions to hospitals for $0-14$ year olds stemmed from
accidents.

Of parasites, ascaris is probably the most prevalent in Afghanistan, with up to $80 \%$ of children in some areas infected. Worms are infrequently life threatening, but a contributor to malnutrition and general debility. Tinea is probably the most common skin infection; prevalence of tinea capitis has been related to constant head covering and poor hygiene. Scabies, flea bites, lice and pyoderma are also common. Eye infections are reported as common with incidence of impaired vision $(1.6-6.9 \%)$, blindness (total or partial) (2.8-6.3\%) and conjunctivitis '(3.3-18.0\%) emerging from a four village rural survey. Main problems may be trachoma, vernal catarrh, glaucoma, cataract, lacriminal disease and conjunctival disease. (Varlous studies reported in Feacham 1978).

Malaria, following a successful control programme in the 1950's and early $1960^{\prime} s$, became a public health problem again in the late $1960^{\prime}$ 's due to resistance of the vectors to DDT and dieldrin. By the mid-1970's Government was trying new strategies but an estimated 6 million people lived in zones of high risk (Feacham
1978 ).

\subsubsection{Morbidity in the $19801 \mathrm{~s}$}

Data for the 1980's on morbidity patterns of Afghan children is again less systematic than that for the pre-1978 period because of the dislocations of civil strife.

\section{Kabul Government Areas}

Data from the Indira Gandhi Institute of Child Health are for children $0-14$ and indicate that $35 \%$ of admissions are for diarrhoeal disorders and 17.38 for acute respiratory infections, with gastrointestinal disorders particularly frequent in children under 5. Likewise, morbidity patterns in $\mathrm{MCH}$ clinics in Kabul indicate diarrhoeal diseases, acute respiratory infections and vaccine preventable diseases as the three principal causes of morbidity. Respiratory infections are most common in the winter months, while diarrhoeal diseases are more common in the summer months. (This corresponds to the findings of Feacham's analysis of data from the Institute of Child Health and the Institute of Public Health in 1978).

High incldence rates for vaccine preventable diseases continue in children under 5 with an incidence rate of 13.54 for measles and 
0.67 for polio. Meningococcal meningitis increased during the as increasing, largely due to Hat, and malaria cases are reported areas. Pigot notes 500,000 in-migration to Kabul from endemic Tuberculosis is increasing. malaria cases in Kabul in 1988. increasing, requiring costl. Leishmantasis is reported as reported at $14.5 \%$ among children treatment. Active trachoma was

\section{Refugees}

Iran - The survey in two districts (WHO/Rezai 1988) ranked diarrhoea as a disease of great magnitude. In the seven days previous to the interview $45 \%$ of the children in the sample had diarrhoea (three or more watery stools per day for more than two not detected. Scabies and lice were also found. Malaria two

Pakistan - The Center for Communicable Disease survey mentioned earlier found that the most common and frequent diseases among refugees were diarrhoeal and parasitic infections, with diarrhoea is three to four times mon children. Tuberculosis among refugees population.

Other reports include diarrhoea, dehydration, measles, tuberculosis, respiratory infections, polio, trachoma, and typhoid
fever as common among children (IRC).

Recent reports following on increased immunisation campaigns suggest a decline in vaccine preventable diseases.

\section{Rural Afghanistan}

Management Sciences for Health reports on data from cross border health workers with three months training on the major diagnoses for children under 5 (Table 9).

Medicins sans Frontières data from Badakhshan and the Hazarajat indicated that gastrointestinal disorders, respiratory infections, musculoskeletal and ophthmalogical complaints and malaria

\begin{tabular}{|c|c|c|}
\hline \multicolumn{3}{|c|}{$\begin{array}{l}\text { TABLE 9 - Major Diagnoses Reported in Children } \\
\text { Under } 5 \text { (1988) By Heal th Workers in } \\
\text { Mujahidin Held Afghanistan }\end{array}$} \\
\hline & $\begin{array}{l}\text { Diarrhoee/Dysentery } \\
\text { Horms } \\
\text { Conjunctivitis } \\
\text { Dehydration } \\
\text { Cormon Cold } \\
\text { Otitis } \\
\text { Injury } \\
\text { Pneumonis }\end{array}$ & $\begin{array}{l}32 x \\
117 \\
8 x \\
4 x \\
47 \\
4 \% \\
3 x \\
3 x\end{array}$ \\
\hline Sourze: & 1988 & \\
\hline
\end{tabular}

accounted for most of the diagnoses of under 15 patients.

While data on present day rural Afghanistan is sparse, of poor quality and limited to areas where medical teams are working, the 
team observations point to high levels and widespread morbidity with diagnoses not inconsistent with pre-1978 patterns.

\subsection{Female Korbidity}

Analysis of adult morbidity by gender usually focuses on separating conditions related to women in their reproductive function, identifying problems of hemorrhage, infection, toxemia, obstructed labour and induced abortion. Analysis of diagnoses of hospital patients by gender, given uncertainties about access to health
care, is not useful.

A Management Sciences for Health analysis of records of health workers inside Afghanistan (1988) indicated the diagnoses of women 15-44 seeking care ( $7 \%$ of the total patients) (Table 10).

Earlier MSH survey work in three provinces revealed higher levels of illness for women than men in all age categories (See Table 1 Appendix I).

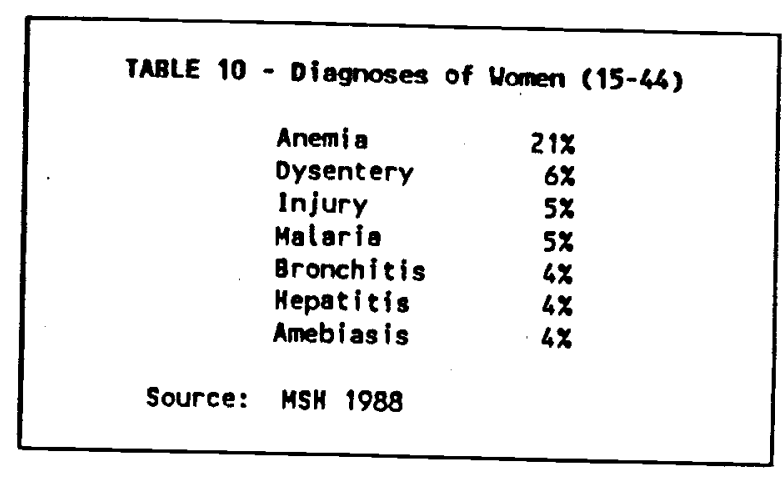

Differentiation by gender of the magnitude and severity of morbidity should be a starting point for design of programmes.

\subsection{TRENDS IN MORTALITY AND MORBIDITY} Recognizing the limitations of the data, tentative generalizations
about trends can be made;

- Overall, the Afghan population has experienced an increase in mortality rates at the same time as mortality indicators have

- Mortality rates have risen most for populations already at risk, and invisible and inaccessible to government or outside
assistance; these include:

- infants and women as refugees in Iran;

- infants, children and women in rural Afghanistan, especially in but not limited to isolated mountain populations;

- infants, children and women among dislocated populations in

- the apparent decline in mortality rates among refugees in Northwest Frontier Province demonstrates the potential for health interventions, but raises questions of how and whether it is possible to build on those achievements if and when refugees disperse to Afghanistan and no longer remain the 
- concentrated target of substantial foreign assistance; constant: diarrhoea, acutear for the most part to remain malnutrition;

- neonatal tetanus appears to have increased.

Quantitative comparisons among morbidity estimates are even more risky than for mortality data. However, the following assumptions - Overall morbidity, traditionally widespread, appears to be

- refugee groups and rural populations isolated from health

- dislocated groups in Kabul and some other urban areas. - Principal causes of morbidity remain diarrhoea, acute
respiratory infections, malnutrition and measles.

- Other infectious diseases remain widespread, and sometimes severe in impact, including polio, tuberculosis and whooping infections and eye infections. appear to be increasing.

- While Incidence of vaccine preventable diseases appears to be declining in accessible refugee camps, particularly in the no evidence of decline of diarrhoea increasing and there is and other less severe infections conditions and practices and to which are related to hygiene

\subsection{NUTRITIONAL STATUS}

Again there is little systematic or reliable data on the nutritional status of Afghan chlldren and women. The data which comparisons which might seem obvious masurement techniques so that obscure critical nutrition problems requirit be misleading and chlldren under five and pregnant mothers in 1-Sharif, Herat, Badakhshan, Badghis, Bamiyan as well as Mazarrepresent one such target group requiring urgent and Baghlan may supplementary and or intensive feeding progrant intervention with

On the basis of a survey of 1-5 year olds in 10 MHC clinics in Kabul (QUAC) and examination of other data, a UNICEF consultant in feeding centres in 3 hospitals, 1989 (Pigot) recommended estabilishment of therapeutic clinics in order to reach itals, 4 general polyclinics and $28 \mathrm{MCH}$ children. Other target groups stimated 2100 severely malnourished feeding: 
Children 5-23 months
Children 24-59 months
Pregnant and Lactating mothers
110,000

250,000

82,000

observational evidence from other locations suggest critical nutritional situations stemming from population movements.

\section{1 protein Bnergy Malnutrition $0-5$}

The following table assembles the results of methodologically different nutritional assessments over time and across locations. Because of the difficulty of assessing methodology, the data cannot be used to illustrate trends over time: the data do suggest that various researchers have regarded nutrition as a serious problem of the Afghan population, and a problem cutting across regions and groups.

\section{TABLE 11 - Protein Energy Malmutrition - Children 0-5 summary Data

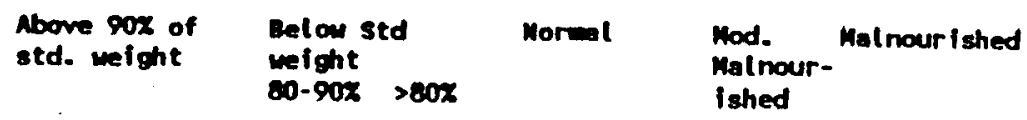

PRE-1976

Kebul Public Health

Insti tute Survery 1976)

Rural (Three Province

Survey, MAC, 1976-77 MSH)

0-1

$1-2$

$2 \cdot 3$

3-4

4-5
$18 \cdot 25 x$

$\pi-82 x$

$\begin{array}{rrr}10.8 & 21.6 & 67.6 \\ 3.0 & 27.3 & 69.7 \\ 10.5 & 49.5 & 40.0 \\ 31.4 & 52.4 & 16.2 \\ 56.4 & 29.5 & 14.1\end{array}$

POST 1970

Iren Birjand/Qaen

Districts (Refugees)

1988 Ugt for Hgt, WHO $\quad 74.7 x \quad 20-8 x \quad 4: 5 x$

Pakisten Refugees

(UNICEF Peshawar 1989)

1984

1985

1986

Kebul Govt Areas (Urban)

Kabul MCH clintes 1988

Kabul НCH clinics 1987

Red Crescent clinics (ounc 1-5, 1989)

ICRC

MCH Clinics (Pigot 1989)

Bural Afohenistan

Badakhshan 1989 (MSF)

$26 \%$

$30 x$

$42 x$

$3.5 x$

$1.9 \%$

$10 x$

Sources: UNICEF 1977; WHO 1989; Pigot 1989; UNICEF Peshewer 1989.

$62.7 x \quad 27.3 x \quad 10 x$


Currently, the most at risk populations are in Kabul and other cities; and in isolated rural areas. Pigot suggests in his analysis that $11 \%$ of the under five population in Kabul is seriously malnourished and that seasonality is a factor. The data to which Pigot had access is institution based and may not include the weakest and poorest, and particularly the dislocatees in substandard and ad hoc housing whose access to $\mathrm{MCH}$ clinics has not been demonstrated. Malnutrition is most severe in winter, following the diarrhoea season and during the period when the already difficult transportation of food is aggravated. He also notes reports of severe malnutrition in Faizabad. While the word famine is associated in the public mind with natural disasters like drought in Africa and flood in Bangladesh, it may not be accurate to see famine as a sudden occurrence. Famine may not be too strong a word for the dislocatees in Kabul and elsewhere. This famine is quiet and hidden.

Refugee populations, with access to food aid, appear from the data not to be at risk for severe malnutrition. Overall data may make invisible small groups of the refugee population which are at risk because of lack of access to refugee rations. UNRISD survey data in Pakistan found that nearly one in five households are not registered and therefore receive neither food nor cash rations. Among these households may also be the ones least likely to be represented in health service based nutrition surveys.

Earlier data, such as the Public Health Institute study in 1976 , which covered middle class and peri-urban neighborhoods, suggest that malnutrition cuts across class/income lines with the implication that nutritional status is related to food practices as well as to access to food supply. This observation is confirmed by the findings across neighborhoods of the MOPH/WHO Kabul survey
(1978).

Data from Management Sciences for Health on pre-1978 rural areas as well as Pigot's 1989 survey and analysis indicate that the weaning period is marked by elevated malnutrition. No data is available since the 1970's on the nutritional status of
nomads.

\subsection{Women}

Systematic data on the nutritional status of women is nearly nonexistent. A 1970 's study from the Institute of Public Health (UNICEF 1977) found that of mothers surveyed in Kabul, only $7 \%$ reached the normal standard body weight for pregnant mothers. Some of the literature on nutrition in Afghanistan notes the link example, high rates of malnutrition the health of the child. For were entirely breastfed are 
(cf. World Bank 1978). As with health data, governments and outside agencies need to develop statistical approaches which count women.

\section{3 other Nutritional Problems}

other nutritional deficiencies exist for children and women, particularly anemia and calcium, lodine and vitamin A deficiency. Data is fragmentary, but all appear to be widespread and some have severe impact.

\subsubsection{Anemis}

Pigot reports a survey at the Malalai Maternity Hospital indicating 47.78 of pregnant women as anemic, though only $15 \%$ had a haemoglobin rate lower than $7 \mathrm{gm} / 100 \mathrm{ml}$. The 1989 survey among under fives at Kabul MCH Clinics showed $6.5 \%$ severe and 23.9\% suspected cases of anemia. Various studies in the 1970's (PHI, CINAM, MSH) suggest the prevalence of anemia among women. The literature relates anemia to low birth weights, and high neonatal and maternal mortality. Malaria and hookworm (common in only some areas) exacerbates iron deficiency anemia.

\subsubsection{Iodine Deflatency}

Iodine deficiency or goitre is endemic in the northern and mountain regions of Afghanistan, including Kabul. It results from a lack of lodine in the rock salt normally used as the source for the diet. In addition to being widespread and a source of discomfort, when found ih pregnant women, it has severe consequences in terms of congenital deafness and cretinism.

A UNICEF study in schools and MCH clinics following rates of iodine deficiency in Kabul:

(1988) found the

$\begin{array}{lr}\text { women } & 25 \% \\ \text { pregnant women } & 16 \% \\ \text { children } 7-14 & 11 \% \\ \text { children } 0-6 & 8 \%\end{array}$

A Medicins Sans Frontlères survey of 2800 females of all ages in Jurm and Teshkan valleys in Badakhshan found that $48 \%$ of the women had goitres (UNICEF Peshawar 1989).

While the problem of goitre has been recognized by Government in Kabul, conditions have not permitted a salt iodization or other comprehensive approach. Some NGOs working across border have dispensed lodine supplementation. Becatise of the visible results of supplementation on an uncomfortable condition, supplementation 
may be a useful tool in establishing the legitinacy of healt
interventions.

\subsubsection{Vitamin A Deflciency}

There is lack of agreement on the nature of vitamin $A$ deficlenc among Afghans. One view holds that vitamin A deficiency is rare and that reports of deficiency blindness result from confusion wit trachoma '(Friesen as reported in UNICEF Peshawar 1989). Plgot 1 Kabul, however, found conjunctival signs of xerophthalmia in 2.4 of children aged 5-14. While his survey found no cases under five other eridence suggested a prevalence of $1-3 \%$, and evidence i Kabul and Herat that incidence of vitamin $A$ deficiency 1 increasing: Increase in vitamin A deficiency may be related $t$ food shortages and the increasing costs of vegetables in urbar areas as well as to nutritional practices.

\subsubsection{Calcium}

There is no direct data avallable on calcium deficiency, but the incidence of osteomalacia noted above in relation to maternal
mortality suggests a problem.

\subsection{Underlying causes - Malputrition}

Many of the underlying causes discussed below in relation to mortality and morbidity are relevant to the problems of nutrition among Afghan people. There klxe issues specific to nutrition, most especially food security, consumption practices, knowledge and attitudes, and policies.

\subsubsection{Food security}

Food security is central to the nutrition problem in Afghanistan. Access to adequate food is affected by fluctuations in production, purchasing power, and distribution capacity, as well as by the knowledge and cultural practices mentioned below. At the present time there are severe food shortages for ldentiflable groups in the population. While there is a lack of precision in describing the food shortage problem, the use of the word famine with respect to portions of the Kabul population and other displaced peoples may

In pre-1978 Afghanistan, aggregnte data suggested that in normal years overall food production was nearly adequate for consumption requirements or a per capita oalorie Intake per day of 2250 , or 7.5 below the FAo standard (World Bank 1978). There were, however, wide Eluctuations in productlop of staple crops, particularly 
wheat, due to rainfall conditions. The annual variation in production was estimated at $\pm 500,000$ metric tons or half the total fluctuations of the domestic market. The variation resulted in producers usually market prices for consumers. small scale wheat stocks were sold at in years of good production as (street 1977).

Warfare throughout much of Afghanistan has disrupted even normal production, and destroyed productive capacity. The Agricultural Survey of Afghanistan carried out by the swedish committee for Afghanistan showed a decline in ylelds for irrigated wheat of $33 \%$ and for dryland wheat of $50 \%$ between 1978 and 1986 , suggesting that total agricultural production fell to about 458 of 1 ts 1978 . levels. There was an 1ncrease in 1987, due to improved ralnfall and decreased levels of attacks. Data from the survey show high levels of bombling of villages, of destruction of irrigation systems and grain stores, and of livestock lost to bombing, shooting or mines. Wheat imports pere 200,000 tons in 1982 ; in 1988 they may have been
at 4-500,000 tons.

In 1989 the intensity of fighting in the countryside reduced, and fighting was concentrated on urban targets. Although a limited number of refugees have returned, substantial agricultural land remalns uncultivated. Good rains and snow for the 1989 season should produce good yields, except in Nangahar Province, where fighting is estimated to have destroyed $20 \%$ of production. Serious food shortages are expected to occur because of the following
factors:

- Internal refugees swelling the population of Kabul will again stretch demand for food beyond domestic supply. Kabul is heavily dependent: on food imported from the soviet Union and transported by truck in convoys. Food supply has been a serious problem in recent winters;

- War damage to communications systems in Kandahar;

- Poor rainfall combined with weak transportation systems are expected to create a food shortage in Eastern Badakhshan;

- War damage in Paktia, Paktika and Kandahar limits production, but these provinces are able to lmport food readily.

\subsubsection{Differentials in Access to Food}

In Kabul, government employees and party functionaires receive coupons which allow them to purchase basic foods at preferential prices. Residents without such access, notably recent migrants to the city, have encountered severe inflation and shortages. In refugee camps, as noted above, a large percentage (20\%) of refugees 
are not registered and thus have no access to cash and food membership. Income and access to to mujahidin political party always been factors creatin to land or means of production have Transportation which enables ding access to food. than in 1978 because of the fribution is a greater factor today transport infrastructure. the considerable damage done to the

\subsubsection{Consumption Practices}

Data on consumption practices are fragmented. Data does reveal positive breastfeeding practices as well as problems assoclated wSH weaning and post-weaning practices and with food taboos (cf. decision-making.

\subsubsection{Breastfeeding}

Breastfeeding is nearly universal among Afghans, in part reflecting isolation from negative trends in the rest of the world. In rural and semi-urban areas, women traditionally breastfeed for 24 to 30 months. The 1973-75 MOPH/WHO survey in Greater Kabul found that the mean duration of breastfeeding was 18.4 months. A 1983 least 12 months and Kabul found that $73 \%$ of mothers breastfeed at (and by extension other more than 18 months (Plgot). In Kabul supplemented with overdilutban areas) breastmilk is often nitiating breastfeeding varies, with a a milk. Practice on For up to one week after bies, with a common practice of delaying often in combination with feeding introduction of breastfeeding, techniques eliminate or reduce the of sugar water; both of which its protection against infection.

\subsubsection{Heaning Practices}

The weaning period is generally acknowledged to be the second most critical period in Afghan child development (see above). Weaning practices which increase the vulnerability of the 1-2 year old nutritional quality of weaning foods; and the foods; the poor breastfeeding. The MSH survey in three; and the abrupt ending of late introduction of weanling foods. provinces in 1976 noted the introduced at a mean age of 11.6 month, with tea and nan being 18 months; and meat and eggs not ths; fruits and vegetables at (reported in UNICEF Peshawar 1989) suggests that $60 \%$ of mothers do not give In Kabul, Plgot (1989) the child is two years old. Weaning supplementary food until quality. An MCH study in Kabul food introduced is of poor constituted $23.4 \%$ of weaning food; bread and that powdered milk 
family food not adapted to the child's needs 20\%. The 1972-75 MOPH/WHO study found that solid food was introduced at an earlier age (average age 7.4 months) than soft foods (average age 9 months). Weaning sometimes occurs abruptly, as when a new pregnancy begins.

\subsubsection{The Family Diet}

Gender, age, income levels, knowledge, and access to food influence the nature of the family diet and the individual family member's access to that diet. Access to food has been 1 imited for most families by the consequences of war.

Following weaning, children will share the family diet, though in a traditional setting, food may have been reserved first for men of the household and secondarily for children and women. The impact of low priority on feeding women and children is not well documented in relation to the high rates of malnutrition for those groups. A CARE nutrition survey in 1970 found most mothers reporting that they never had enough to eat during pregnancy. This corresponds to the Institute of Public Health data that only $7 \%$ of mothers reached standard weights for pregnant women. The relationships among food shortages, intra-family food distribution, and malnutrition need to be made visible.

Food has been an important part of Afghan culture and of the Afghan family budget. A Household Expenditure Survey in Lashkar Gah (Helmand Province) conducted by the Ministry of Planning in 1968/69 estimated that rural families spent $65.6 \%$ of earnings on food; an urban family spent $60.7 \%$. The UNICEF funded CINAM study in the north of Afghanistan (1973) produced evidence suggesting family interest in a varied diet. They found a high income elasticity among low income families for meat, fruit and vegetables, and for milk products and eggs at higher income levels. survey and observational data in the Hazarajat suggest an absence of vegetables and a lack of knowledge about the role of vegetables in the diet.

In the 1970's the typical diet of a labourer or small farmer household was described as including nan (flat bread which serves as the staple), soup or sauce and yogurt with tea. Milk was rare. on special occasions meals might include rice pilaus, meat and sweets. Frults and vegetables might be avallable in season (World Bank 1978).

In 1989, the diet in an ordinary Kabul home was described as sufferting from the decrease in purchasing power and consisting of nan, tea without sugar, and sometimes a soup containing some vegetables and potatoes. Families may have a protein supplement (meat, egg or milk) only two or three times a week. Vegetables and fruit are expensive in the market (Pigot 1989). 
Among refugees the ald ration includes wheat, sugar, milk, tea and edible ofl, which may be supplemented by purchases from the market depending on income.

\subsubsection{Food Taboos}

There are a number of food practices or taboos in Afghanistan, not well documented by type or area of practice, which have a deleterious effect on the nutrition and health of children. The taboos include breastfeeding, weaning practices, diet during illness, pregnancy, postpartum and lactating perfods as well as theories about 'hot' and 'cold' foods. For example, treatment of diarrhoea among some groups, includes the witholding of all liquids. In other cases, eggs, even when plentiful, are forbidden to young children. The existance of harmful food practices or remedies will remain an obstacle to introduction of improved nutritional habits.

\subsection{Nutrition: Knowledge and Attitudes}

Though male literacy and access to outside information is greater than that of females (see below), neither men nor women have a clear idea of the role of diet in individual and family well-being. within the context of expanding food security, the important nutrition messages for children and women related to the specific nutrition problems identified above:

- improved weaning foods and practices to reduce the vulnerabllity of children at the weaning stage; this would include timely introduction of appropriate local foods;

- encouragement of current breastfeeding practices, but discouragement af powdered milk supplementation;

- promotion of breastfeeding following birth to take advantage of colostrum;

- identification and popularization of appropriate diets for pregnant and lactating mothers;

- promotion of Vitamin A rich local vegetables;

- popularization of lodine supplements, as well as Vitamin $A$ and iron supplements.

Attitudes influence whether knowledge is applied. Given Ingralned food practices in Afghanistan, along with patriarchical patterns in the soclety, targeting fathere. school boys and leadership with information and advocacy may be necessary to influencing change. In 1978 the World Bank, in noting that part of the nutrition problem is educational, called for "making fathers aware of the special nutritional needs of expectant and nursing mothers". 
5.0 OLDERLYING CAUBEB OF MORTALITY, MORBIDITY AND MAINUTRITION

Diarrhoea, acute respiratory infections (including tuberculosis and pneumonia), measles, neonatal tetanus and malnutrition are the principal and immediate causes of mortality and of morbidity among Afghan infants, children and women. Pollo, malaria, whooping cough, meningitis are among the other severe but less widespread causes of mortality and morbidity. Parasites, skin infections, eye infections and nutritional disorders such as goitre, anemia and Vitamin $A$ deficiency are widespread, and contribute to debility and the severity of other disease.

with the partial exception of malnutrition, these causes of mortality and morbidity can be substantialiy prevented through simple technologies or simple improvements in health and hygiene practices. Where morbidity occurs, its severity and duration can be reduced through simple, sometimes home-based care. Handwashing, oral rehydration therapy, immunisation and improved weaning practices would all have direct impacts on levels of morbidity and mortality.

The one exception is malnutrition and famine. Absolute shortage of food and of essential nutrients is the situation of a significant portion of the Afghan population. It is not possible to quantify the size of this population, but the evidence suggests that substantial numbers among the internal refugees in Kabul and other cities, plus groups in rural areas severely affected by the war, as well as refugee population with no access to aid rations, may be at risk nutritionaliy. Prevention and improved nutritional knowledge are of little help in the absence of food.

To understand the continuing prevalence of easily preventable or treated causes of morbidity and mortality, it is useful to look at the nature of health decision-making, health polfcies and services, the health environment, and the health knowledge, attitudes and practices of the general population.

5.1 Patriarchical social Organization and Health policies and practices

The patriarchical nature of Afghanistan permeates the programmes, if not always the state policies, of successive governments, resulting in government health systems which are oriented toward the adult male population, or the group least at risk, and toward urban areas. The bias $n$ the pre-1978 health system toward urban male clients is noted below. Even the current Kabul Government, which has a clearly articulated policy on maternal and child health and which has significant accomplishments in training of female health workers, has not been able to reverse the urban, male, curative blas of the formal health system. Patriarchy also continues to Influence the bias of NGO, local and informal health systems which have always existed or which have been growing in 
areas not controlled by the Kabul Government.

In those exceptional instances where health services have women, it has targetted primary and preventive care for children and or through a new Government's success in reaching commitment as in the Kabul Kabul.

\section{1 .2 Health Policles and Bervices in the 1970 's}

Though the seven Year plan identified infants as the highest priority group, actual expenditure reveals contrary real priorities. In 1977 Management Sciences for Health, working with the Ministry of Public Health, undertook an analysis of health expenditure and demonstrated an expenditure bias toward target
groups least at risk (adult males) and toward urban areas.

Table 12 shows that infants who suffered $40 \%$ of the mortality recelved only 6.18 of health expenditure. Adult males were the focus of $54 \%$ of expenditure. During the 1970's efforts to redress formal health system bias toward urban, male curative care did emerge from MOPH collaboration with outside donors and the advocacy efforts surrounding the global conference on Primary Health Care in 1977. Principal innovations included efforts to expand the number and quality of Basic Health centres, 116 of

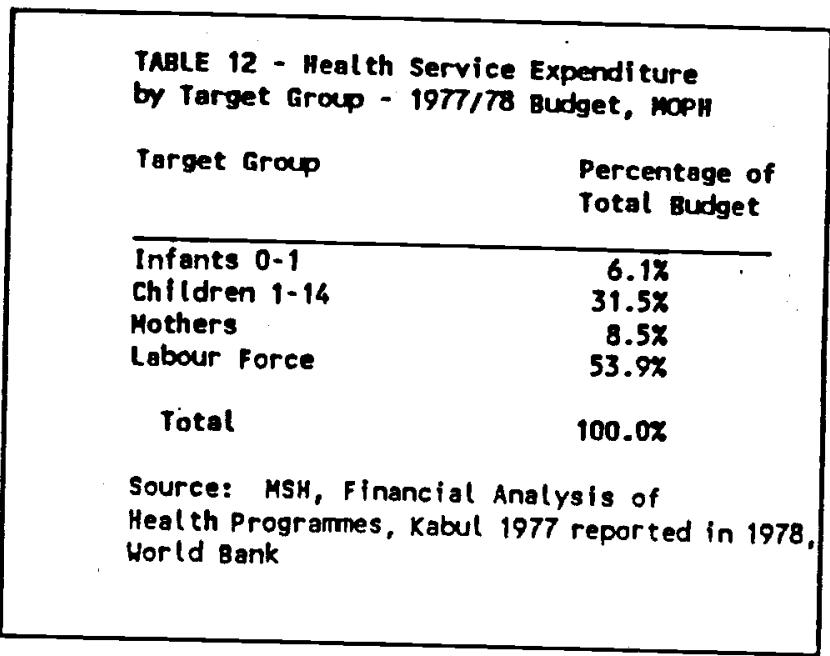
which were outside of Kabul Province in 1977 (UNICEF 1978). The BHCs were intended to serve a multi-purpose preventive and curative role with a seven person staff headed by a doctor and including a female auxiliary nurse/midwife. In fact, however, the Basic Health Centres were able to reach only $6 \%$ of the population in the 1970's. Analyses suggested that the BHCs had a 1 imited catchment area and were able in $1976 / 77$ to handle only 495,000 visits. Moreover, the average number of visits per day to each of the BHCs was less than 12 persons. The Government sought to expand coverage by opening health subcentres staffed by a nurse and a vaccinator. Difficulties of posting staff, particularly females, to rural units and a serious drug supply and management situation contributed to the severe underutilization of facilities. Whatever the coverage achieved by the BHCs, they were, nonetheless apparently held in high regard by the population. An MCH three province survey in 1977 found that only $7 \%$ of men interviewed would forbid daughters 
or wives to attend the BHC. (World Bank 1978).

Recognizing the limits of BHCs, the Government had begun in the late 1970's work on the development of a self-financing village Health Worker Programme and on training of traditional birth attendants (dias) in simple preventative measures.

\subsection{Health Bervices in the 1980 's}

\subsubsection{Kabul Government Areas}

Resistance, war and budget constraints limit the ability of the PDPA Government in Kabul to reverse the urban, male, curative bias of the health system. Little budget data 1s. avallable, but wha! is avallable suggests that the current Government has increased the: percentage of total budget allocated to the Health Ministry from $1.5 \%$ in 1977 to $2.8 \%$ in 1979/80. In 1987 the percentage of national health expenditure devoted to primary health care was estimated at $33 \%$ (Pigot). A comparison of health personnel between $1976 / 77$ and 1987 suggest a substantial improvement in numbers (Table 13):

such a comparison suggests a significant increase in doctors and nursing staff per population. However, data are of limited use in making comparisons because of the movement of medical personnel to Kabul and other cities, increased demand on
TABLE 13 - Health Workers to 1000 Population Ratios

\begin{tabular}{lcc} 
& $1976 / 77$ & $\begin{array}{c}1987 \\
\text { (Kabul) }\end{array}$ \\
\cline { 2 - 3 } $\begin{array}{l}\text { Noctors } \\
\text { Nurses } \\
\text { Feldschers/Nurses }\end{array}$ & $1: 12,900$ & $1: 1851$ \\
\hline
\end{tabular}

Source: World Bank 1978 and Pigot 1989.

hospltals and other services resulting from war casualties as well as because of geographic limits of the Government. What is a remarkable achievement are the strides made in educating women as medical professionals; there are now an estimated 300 female doctors and 3,000 female nurses employed by the Kabul Government. More than fifty per cent of the medical students enrolled at the two medical colleges in Kabul and Nangahar are women. Overall, more than 3,000 women were (1987) enrolled in professional health training programmes, Including as Feldschers (GOA 1987), a programme whirh has reportedly recently been discontinued (Pigot).

Government has recently reactivated training programmes for midwives and for dais, extending the opportunities open to female health professionals. Plgot notes that the level of medical personnel in Kabul is currently adequate for the population levels, an abnormal situation resulting from the flight of personnel from the countryside. During the process of reconciliation, it remalns 
to be seen whether personnel formerly based in rural or small urban facilities will return, or whether the soctal environment will encourage newly trained medical personnel to serve in rural areas. Table 2 in Annex I provides the basic government data on health infrastructure by province. As can be observed, a good percentage of these units and personnel are outside areas controlled by Government and may no longer be operative.

Another notable effort of the Kabul Government has been to involve the community in health education through mass based organizations such as the Democrative Women's Organization of Afghanistan, the Central Women's Clubs and the Democratic Youth organization. Not enough is known about the shealth education activities of these groups and their effectiveness in influencing health and hygiene

While data is not available, health institutions in the Kabul Government areas are severely short of drugs and supplies, hampering efforts to provide basic services. Hospitals servicing
war injured children are under particular stress.

The National Child Policy adopted by the Council of Ministers in 1986 gives priority to speclal welfare programmes for children, including immunisation, curative care, nutrition and special care for disabled and indigent children. Where the Kabul Government has a health infrastructure some significant accomplishments in terms of coverage have been achieved; coverage is, however, 1 imited to Kabul and other urban and semi-urban areas. Moreover, the structure of government health services remains biased to curative and urban rather than household and female needs.

An estimated $46 \%$ of the hospltal beds and $83 \%$ of the MCH Health Clinics are based in Kabul. While there are a reported 140 Basic Health Centres and sub centres located in rural areas, many are Kabul, statistics of control of the Kabul Government. Within clinic regularlcs suggest that $33 \%$ of children 0-5 attend MCH the same (PIgot), and the rate for women is estimated to be about of children (1-2) A household survey in Kabul indicates that 808 immunisation is carried fully immunized, and data suggests that (out of 29). In Kabul ORS access ratent in 13 other provinces estimated at $11.7 \%$ and ORT use rate is 35\%; ORS use rate is earlier, $25 \%$ of births in Kabul occur e at 25.9\%. As indicated an additional $15 \%$ are attended bind trained dais (Pigot).

Table 3 in Annex I showing the organigram of the current Ministry of Public Health suggests how the structure of health services perpetuates the urban and curative blas of government health care. located in the pepartment Primary Health Care. It is however, a separate MCH programme of Curative Medicine, which also directs elements of primary health with hospitals and polyclinics. The 
programmes: Health Education, Tuberculosis, Malaria and Leshmaniasis, sanitary Epidemiology Including EPI, CDD and water and sanitation all run vertically in the Department for preventive Medicine. Family planning inputs are provided by a separate organization outside the Ministry, the Afghan Family Guidance Association, which nonetheless provides services inside $\mathrm{MCH}$ CLinics. There is one NGo operated eye hospital (Noor). The Red Crescent, assisted by ICRC, runs a first ald clinic which provides curative care and immunisation to children. A second NGO, the Halo Trust, runs a general care clinic In Kabul (Pigot). In theory, the Deputy Minister for preventive Medicine can coordinate primary health care through his control over all the health institutions. In practice, the current structure builds in high potential for faulty communication and lack of coordination.

\subsubsection{Rural Health}

Although large parts of rural Afghanistan have endured sustained human and infrastructural devastation in the past eleven years, a fragmented, locally based primary care system has slowly been emerging in some areas. Heavily supported by NGos and, more recently and indirectly, UNICEF and the United Nations system, and linked with political parties, military commanders and iocal leaders, the health care has moved from treatment of war casualties to curative care and limited preventive. activities including an immunisation campaign. Children and women remain underserved, but today, some rural Afghans may have better access to health care than they did in the pre-1978 period. Tomorrow, when the forelgn financial and technical support dissipates, Afghans may not be able to afford the rural health system which has sprung up. And tomorrow, Afghans will have the task of reconciling far flung and disparate services into a system which can be sustained by government and community resources.

Rural Facilities, Personnel, Bervices and Coverage - Cross-border health services are provided through the Alliance Health Committee (AHC) and the coordination of Medical committees (CMC). The AHC is composed of health representatives of the political parties in Peshawar and has been supported by Management Sclences for Health in the selection and training of Basic Health Workers. The CMC coordinates the cross-border activities of $13+$ NGOs and attempts to standardize drug 11 sts and training.

Table 14 indicates that in 1988, significant numbers of facilities and personnel were functioning in rural areas not controlled by Government.

Differing totals number of health be considerable exceptions among are available from other sources on the overall personnel trained and working; there is sald to dropouts among those trained. With limited the expatriate teams, the staff are male. Maps 
of the distribution of medical personnel are avallable in Annex II. In general, there are more medical personnel in the eastern provinces bordering Pakistan, and among Northern, and to some extent Herat based, commanders who have given priority to establishing civilian services.

The first cross border medical interventions were aimed at war injuries. Foreign medical teams maintain hospitals in wardak, Bamiyan, Ghazni and Parwan.
TABLE 14 - Heal th Facillties and Persomnel In Rural Arees outside Covernment Control

clinics

Total Heal th Uorkers 291

first Ald Workers $\quad 700$

(2 months training)

Mid level Horkers

(6-9 months training)

Basic Health Workers

(3.6 months training)

Medical Ooctors

Murses

700

800

800

96

236

Source: UNICEF Peshawar, 1989

Most facilities, however, are small clinics staffed by 2-5 medical workers who may have been trained from three to eighteen months. Some clinics may be attached to resistance fighting units. The vast majorlty provide primary, curative health care. over time and particularly as securtty has improved in specific locations, medical care has increasingly gone to meet general health needs of the population remaining in rural areas. A recent CMC analysis of 57,000 diagnoses from three different areas of Afghanistan suggests that the vast majority (98\%) of patients come to health clinics for non-traumatic medical complaints. At the same time, data suggest that women and children have little access to cross border health care. MSH analysis of patients treated by the AHC Basic Heaith Workers found that only 28 of patients were under age 5 , and only $7 \%$ of patients were female. Other NGOs have reached a higher proportion of women. International Medical Corps in a 1987 analysis of 22,000 patient encounters found that $28.4 \%$ of patients were women and $25 \%$ were children under the age of nine.

Since 1987, and with the substantial support of UNICEF to make immunisation available to all Afghan children everywhere, an immunisation programme working cross border through NGOs was inftiated. presently, 11 NGOs are delivering immunisations using a two dose measles, BCG, combined DPT with killed augmented pollo for children and tetanus for women. A new NGO, the Afghanistan Vaccination and Immunisation Centre (AVICEN) has trained 200 vaccinators. Targets are to immunize 300-500,000 children and 150200,000 women by the end of 1990. Immunisation activities are focused in the Eastern Pakistan border provinces, the Northern provinces and Herat where the NGO work is concentrated and where security and local leadership conditions are conduclive to an immunisation campaign.

Progress reports on implementation of immunisation inside Afghanistan are positive. The cold chain has not been a difficulty despite the long distances and varying climates through which the vaccines must be carried. The success is due to the high quality of equipment used as well as the high level of commitment and 
management of the NGos involved. Both factors may be difficult to sustain for the long run. other success factors were related to political security, the support of the resistance parties, and support from military commanders and community leaders. Reaching women and also infants in Pashtoon ateas has been difficult. (UNICEF Progress Report, EPI Programme for Afghan Children Everywhere) .

other small scale preventive activities inside Afghanistan include limited distribution of oRs packets and lodine, iron and vitamin A supplements through NGo activities.

Comparison of rural health delivery before 1978 and at the present is not meaningful as data are neither reliable nor developed from a comparable base. Nonetheless, the evidence suggests the possibility that for some rural Afghans, chiefly adult males, there is better access today to primary curative care than in 1979, and that immunisation services are being delivered to children and some women who previously had no access before, UNICEF Peshawar estimates that roughly $\$ 200$ million a year may be going into cross border health activities. In 1977-78, the total health expenditure of Government was planned at $\$ 13.3$ million. (World Bank 1978): In 1988, there were 291 health clinics in rural areas. In 1977 there were 122 Basic Health Centres, plus limited subcentres. In 1988 an estimated 2600 health workers were working in rural Afghanistan. In 1977, a total of 2943 health workers were employed in urban as well as rural Afghanistan, and of the 719 doctors included in that figure, most were in Kabul.

\subsubsection{Refugee Health}

Health care may also be more accessible today than in the recent past to the $85 \%$ of Afghan refugees who came from rural Afghanistan. The Afghan Refugee Health Programme (ARHP) seeks to provide MCH, immunisation, curative care, basic drugs, disease control and health education through a system of Basic Health Units (BHU) and sub Units. The BHUs are staffed by a medical officer, a Lady Health Visitor and other staff. The health services are run collaboratively by the Government of Pakistan, UNHCR, and NGOs. In 1988 there were a total of 193 BHUs and sub-units for refugees in North West Frontier Province. With an officlal population of 2.2 million refugees, this provides a coverage of one health unit per 11,400 population. Similar data is not available for Baluchistan and punjab, and there is little information on health services for refugees in Iran.

The decreases in refugee infant mortality rates noted above suggest the extent of coverage enjoyed by the refugee population as compared to their previous situation.

Immunisation has been a major preventive health undertaking and in 
1988 the Immunisation effort moved from a static, health unit based effort to mobile and campaign efforts and focused on training and showed that a low percentage A survey on coverage during 1988 Immunized, 22\%, while 65\% had of children under two were fully partially or fully immunized. The survey a total of 798 were fully immunized with tetanus toxold, and showed that 59\% were partly or fully immunit cards and histories 1089): NGos based in Pakistan have initiated a number of training
programmes for mid-level female health workers, Lady Health
Visitors and dais in the refugee camps (Save the children/Uk International Rescue committee/Hangu, CHREP/Mansehra, Salvation Fund and others). An estimated 800 women have Committee, Mercy Traditional Birth Attendants (dais) women have been trained as $1988 j$.

\subsection{Healthe Nater ganitation and Housing}

The environment in which Afghans live explains much about the transmission of disease and the high morbidity and mortality. sanitary excreta disposal were largely and personal hygiene and urban households. The problems of the absent in most rural and by the destruction of rural systems past have been exacerbated systems by swollen populations systems and the overtaxing of urban in poor urban areas and is . Overcrowding in housing was common facilitating the transmission of air borne infection.

In a 1978 survey for UNICEF of avallable data on water supply in Afghanistan, Feacham found that only $3 \%$ of the rural population had remainder relied on piped or hand pump water sources, while the karez (underground tunnel) (irrigation canal), howz (open tanks), water. For the protected systems, a uning or unprotected weli that 50\% of handpumps and $60 \%$ of power forcing people to return to polluted water were not functioning, systems were 1 imited to $\mathrm{Kabul}$ and severater sources. Urban wäter for most of the population wells (46\%) or no direct access through standpipes (28\%), private carriers or other means. (World Bank, 1978).

Likewise, adequate excrete disposal systems did not exist. Feacham households in a village might have latrines elther open vaulted or unimproved latrines. The latrines were uniformly used or well maintained. Most latrines and were not while children defecated inside the hout Afghans used the flelds, was exposed to flies and opportunitlesold compound. Excreta infection. school data show that onlyities for transmission of and that many of these were 111-malntalis of schools had latrines 
Basic Health Centres lack sanftation and water facilities.

In pre-war Afghanistan, housing was not a major problem, with rural housing produced out of largely locally available materials. Urban housing tended to be smaller than the average 2-3 rooms of rural houses (World Bank 1978). The considerable destruction of housing in the past ten years, combined with the depletion of Afghanistan's limited wood resources, complicates housing rehabilitation and increases demand for scarce timber resources which are Afghanistan's principal low technology source of fuel.

\subsection{Rnowledge, Attitudes and Practices}

A frequently cited study (MSH 1977) suggests that Afghans are willing to spend their income on modern or traditional cures. A low. level of health knowledge and attitudes and practices which fail to acknowledge the true causes of disease and disease transmission mean that private health expenditures result in little health improvement.

Afghans have little comprehension of bacteria and viruses and patterns of disease transmission and traditionally had a great bellef in jinns and evil spirits as the cause of disease. Afghans have turned to modern cures, anti-biotics and infections, as the new supernatural forces which conquer disease and suffering. Health workers in Pakistan and Afghanistan complain of abuse of drugs and a magical belief in injections. Misconceptions about medicines may be shared or reinforced by Afghan leadership which has used its leadership role to give priority to curative health, and to ignore the importance of preventive measures. The health knowledge of future leadership, and their willingness to act on that knowledge, will condition future health levels in Afghanistan.

Where a preventive programme like immunisation appears to be succeeding with Afghans, it is in part because of the population's bellef in the benefits of the injection. Moreover, local populations reportedly can see the impact of immunisation on incidence of measles and other diseases (UNICEF Progress Report 1989). Immunisation does not require the active participation of Afghans beyond presenting themselves for the course of injections.

The low level of health knowledge continues because of the low level of literacy, and the very limited health education available (see below).

Attitudes about women limit their access and that of children to health services which exist. The tendency to seclusion of Afghan women stems from tribal traditions related to patrilineal inheritance of property and the consequent importance of assuring paternity of children. The honour of the woman becomes bound to the honour of the family and the family is bound to avenge threats 
to this honour. In the Pashtunwall or code which governs behaviour of Pashtuns, this is called namus or defense of the honour of the women. All traditional and rural groups seek to shleld women from which would threaten the guard agalinst dishonour or even gossip revenge. (cf. Dupree the family hohour and call for violence or of honour to the communt $124-27$ ). It is because the appedratice to expand the should be recognizs of women are difflcult. At the same timej, it differences in the that there are regional, class and educational where the code the access of women to services. Moreover, even some tradition of women's rights and is strong, there also exists

Nonetheless, the lack of knowledge of men and women about sound health practices and women's lack of control over access to health services and education perpetuate practices which threaten health. For example, surveys have shown marked preferences for drinking jui (canal) water as having a better taste than water from protected sources. Also traditional is the belief that any flowing water is clean. There is some anthropological literature which describes some of the rural health behaviours in Afghanistan (see communities may be a prerequis the practices in use in specific females work outonals. This, combined with reluctance to have of recruiting status in which trade health staff. On another level, the low discourage doctors and groups hold the health professions may serving in rural areas. Difficulties trained professionals from for rural service are noted in present cross border operations.

While the focus here is on negative traditional health practlces, there are positive practices which need to be encouraged, such as lactating mothers or fing, at the same time as improved diets for

\subsection{DIBABILITIES}

There is no statistical data on the extent or severity of disabilities among Afghans. War related injuries have demonstrably increased the incidence of disabilities, but disabilities resulting from immunisable diseases or dietary deficiencies are also believed
to have increased as an indirect result of war. Particularly
vulnerable to the consta vulnerable to the consequences of disability are women and female children who have less access to treatment and rehabliftation
services. 
6611 Disability patterns

Mendis (1989), on the basis of data from Pakistan, suggests that the most frequent type of disability is of movement, as a result of war wounds and mine infury amputations, paraplegias and burns. Additionally, polio (among children and adults) and cerebral palsy are also common. Reports from Kabul (Burns, New York Times, December 3,1989 ) suggest that mines have been the most destructive weapon of the war, killing and maiming tens of thousands of people. Hospitais in Kabul are filled through the corridors with victims, particularly children, who have lost 1 imbs and eyes to mine explosions. Plgot (1989) suggested that disabilities to children were mainly upper body disabilities, resulting from the 'butterfly' devices scattered around the countryside.

Also found, as a result of war or of inadequate health services, are visual disabilities, mental retardation, mental illness, hearing and speech problems. Epilepsy is thought to have increased because of head injuries and post-concussion syndromes. Mendis suggests that the incidence of severe disablitities among Afghans will be lower than expected from a war torn situation, because of inadequate support services and high mortality rates.

Studies from the Psychiatry Centre for Afghan Refugees in Peshawar suggest a $40 \%$ increase in mental illness over pre-war times. Mental illness results from multiple traumatic stresses of war; bombing, deaths, infuries and flight. Mental illness appears to be higher among women refugees (Habibi 1989), probably aggravated by the isolation and heightened seclusion they experience in refugee camps. Mendis suggests that the extent of depression, personality disorders and other forms of mental disability among children are a result of traumatic experience and will only gradually be revealed as children grow up.

\subsection{Continuing Disability.Risks}

Mines represent a continuing and severe threat to health inside Afghanistan. Estimates of mines seeded in Afghanistan during more than ten years of war vary: there are at least three to five million. UN field missions in Afghanistan have collected samples of 26 different types. The 'butterfly' poses the greatest risk. Made of plastic, it is difficult to detect and has been scattered in large quantities from the air. It is designed to maim rather

To the extent that preventive and primary health care (particularly polio immunisations) is expanded (see above), the risk of disablilty due to disease has potential for reduction. 


\subsection{Fulnerable Groups}

Children, females and women married to disabled heads of households are particularly vulnerable to incidence of disability; or the effects of disability. As noted above, children are thought to be more at risk for injury from mines and particularly anti-personnel devices. Females of all ages are significantly less likely to have immunisation, or for tre measures such as mine education or presents data on clients that female access may be as rehabilitation workshop suggesting than $40 \%$ of clients under 15 as 17 to $15 \%$ overall, and less disaggregated data on incidence years of age. While gender avaliable, sliwinski's data of war related injuries is not significantly greater injury from suggest that females suffer to disabled men may face multiplenting than men. Women married generating opportunities while taking burdens of needing income care. The traditional capacity handicapped members into the war.

Prevention, Rehabilitation, Education and Mine Removal Programmes

In Kabul and from the Pakistan side, programmes are already in place to prevent and address the problems of disability. Expanded above. They have the calmed at Afghans everywhere, are described from polio. Vitamin A and to reduce significantly disabilities widespread, could address define supplement distribution, not now which increases incidence of cretini related blindness and goitre rehabilitation programmes and cetinism. Hospitals for treatment, exist in both Kabul and Pakistantres for production of prostheses of meeting demand these institutions it is not known how far short the mentally ill and with capacity to work with particularly limited.

Mine awareness and removal programmes have started in both Kabul and from Pakistan with support from a variety of sources. The UN is directing a coordinated effort from the Pakistan side for mine efforts are dependent and medical training. Major mine clearance years to complete.

Principal Constraints to programme Implementation

Social restrictions will limit the access of women to all types of prevention and rehabilitation programmes. There appears also to physiotherapy and of Afghan parents to take advantage of Mendis noted that only one third of for disabled children. 
physiotherapy turned up for the service. Afghans do, however, express a preference for rehabilitation services which keep the disabled within the family. 
51

\section{PART IV - EDUCATION}

\subsection{OVERVIER}

The educational status of Afghans ranks among the lowest in the world. Access to formal and informal educational opportunities has poor. Civil war has further reduced the quantity and frequently of educational opportunities available to quantity and/or quality

War has destroyed perhaps two thirds of the physical infrastructure built by previous governments, decimated the ranks of teachers and collapsed the meagre educational support system. War has hobbled the efforts of the present government in Kabul to implement its the overall decline differs education and 1 iteracy. The impact of the severity of the effects of locations, gender, ethnic group and new access. Female students in war. For some, events have created education than before. For most, however, the quality of education
has declined. The Internally disploter access to affected areas inside Afghantisplaced populations and war opportunity to attend school. For some groups significantly less training and education needs. Widows, wives of disabled persons, income generation.

Finally war has left an impact on the generation of the young. The lives of many are marked by exile in the artificial environment of the refugee camp. Most experience the emotional trauma of the existed of of war, and the political divisions which rend what

Analysing the present situation of education for Afghans is more complex than sifting through sometimes conflicting and unverifiable data by location, gender, group and time period. Underlying the current situation 1 s the continuing lack of a shared hational vision of the purpose and nature of education. There $1 \mathrm{~s}$, however, remarkably little diversity among Afghans on the process of education, with most seeing education as a didactic process where the child is an empty vessel into which information is poured.

This section seeks to describe the existing educational situation for Afghan children and women and the uhderlying causes; and to identify the principal issues for education development which emerge. Education is defined broadly to include a variety of informal as well as formal expertences. Thete is an absence of data on education in Iran, except for the information that some children are attending normal Iranian schools. For this reason, the children and women living in Iran are not included in this
analysis. 
2.0 PRINCIPAL INDICATORB OF THE EDUCATION OITUATION

A review of the available data on principal educational indicators reveals the low state of education among Afghans; the nature of the decline which has occurred; and, within that decline, the advances
which some groups have gained.

\subsection{Itteracy}

The capacity to read and write is not an end in itself, but an avenue to a wider range of Information and ideas. Research has demonstrated a significant link between the educational level of the mother and the survival of the child. The continuing low literacy rates among Afghans, and particulariy females, corresponds to the continuing high infant and child mortality rates. Estimates of 1 iteracy rates vary by source, but together they suggest some
trends.

The Government in Kabul has placed high priority on 1 i ter a c $y$, particularly for women. In 1986, for example, there were a total of 371,000 enrolled in literacy classes, of whom 160,000 were female. In 1977 only 30,000 (male and female) were enrolled in literacy classes. The Government programmes for female literacy have, however, been politically divisive. It was the promotion of 1fteracy classes for women, sometimes by coercive means | and 1979 which helped to spark the mujahldin rebellion. While TABLE 15 - Afghan Literacy Rates (Urben and Rural there available)
Afthanisten

1977 (National

Directorate of Adult

Education

1978 (General Agency

for Litersey (ampoign)

1985 (Morld Benk)

1988 (Rasil Basu from

Pakiaten

1988 selected FHW/TBAs

In Paklstan Refugee

Camps (Comor)
Goverment Sources)

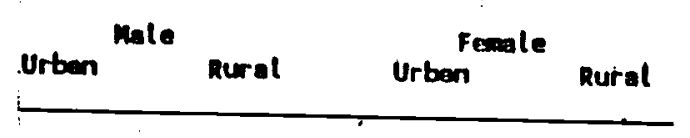

$36 x \quad 16 x \quad 15 x \quad 1 x$

$20 x \quad 10 x \quad 10 x \quad 1 x$

$39 x \quad 8 x$

$25-30 x$

$19.4 x$
Sources: UNICEF 1977, 1978; Moghadan 1989; Basu 1989; Cornor 1988 Kabul government programmes are not permanent, outs lde observers classes and the the widespread participation of women in 1iterdcy ifteracy and in mobilizing women's organtzations in ptomoting pakistan, although Connor's sk111 inventory found that 19.4\% of 
Female Health Workers/Traditional Birth Attendants reported being literate, data available do little to indicate current literacy levels. The evidence on school attendance and quality (see below)
suggests a decline in literacy rates for females.

Literacy can to some degree be used as a proxy for measuring the access women have to new ideas and to means of influencing change in their own behaviours. To understand the capacity of rural Afghan women to receive and use new information for the welfare of their families, it is useful to go beyond literacy as the ability forms of communication to look at the access and exposure to new remain illiterate, the nature of that women, in particular, may Traditionally rural Afghan women might spemeracy may be changing. a single valley without interchange with their entire lives in reporting on refugee women, notes the vith outsiders. Connor, formerly rural women whose isolation very narrow view of the Afghanistan limited their access to sour prior to flight from films, markets) beyond their own and related information (radio, life was not porous to new ideas.

The refugee experience has had differing and sometimes contradictory effects. Within the camps, households have been tribal affiliations. a greater degree than was necessary in wom have been secluded to Relief agencies have encount necessary in the ancestral village. access to refugee women. formerly rural women has been infant mortality among pakistan pierced. The significant drops in indication of the access of Moreover, women have become dirth services to women and children. interventions, particularly vaccines, to reduce the power of health forms of communication, radio and television, may havelity. other accessible to women in Pakistan. Widespread wave become more breakdown of traditional social support widespread widowhood and the forms of economic need, have support mechanisms along with other employment and income generating activitsome women to seek paid in Peshawar and other cities may haves. Self-settled refugees experience than in rural or small town afghanistan. Ten years of views of Afghans.

\section{Access to Primary Education}

Comparing the number of schools in the pre-1979 period with the number operated by the Government in Kabul gives a misleading picture because it does not include schools operated for refugees in Pakistan or the increasing number of schools operating in areas added together, outside the control of the kabul Government. If added together, there appear to be nearly as many schools operating 


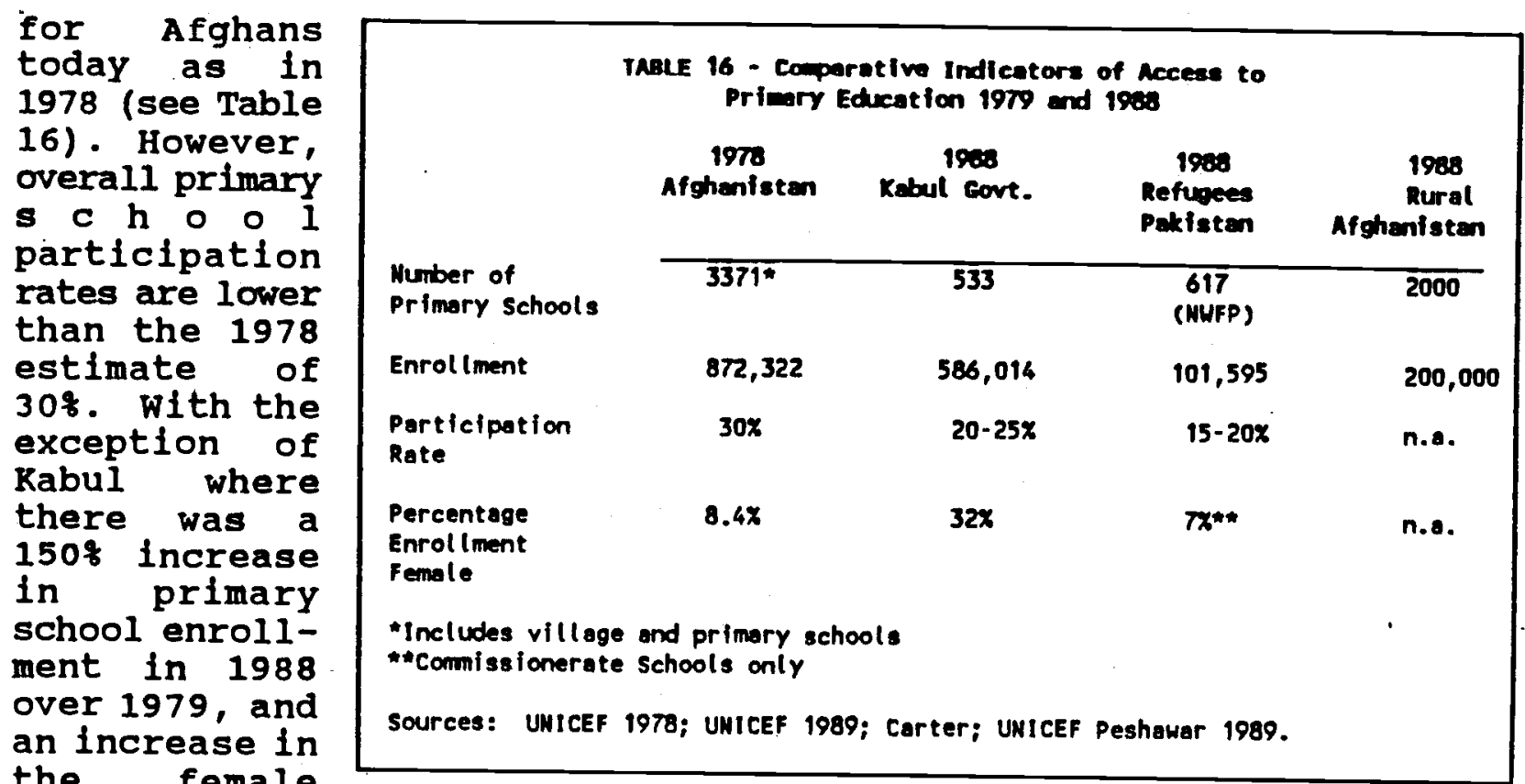
the female primary enrollments, access elsewhere has declined. Moreover, there is substantial evidence that the quality of primary education, weak in 1978, has declined largely due. to the destruction and disruption caused by war.

Fastage - Indicators of the quality of education can be found most concretely in the high dropout or wastage rates. Afghan schools have always been inefficient. Nystrom, in a 1977 UNESCO study using 1973 data, found such a high rate of dropouts and grade repeaters that for every male sixth grade graduate, the school system provided 15.2 years of education, or about two and a half times the minimum six years. For girls the system had to provide 18 years of education,. or three times the minimum, for each primary school graduate. Because of the high rates of drop outs and repeaters, investment on years of education is wasted on individuals who drop out before becoming literate.

While comparisons are not accurate because of changes in promotion and examination policies, wastage may remain a serious problem in schools operated by the kabul Government. Data from student reglsters in Kabul suburban schools analysed by a UNICEF consultant (Shresthra) in 1989 indicated a dropout rate of around $50 \%$ in grade one and 15 to $25 \%$ in other grades. There was a retention rate of $15 \%$ in grade one.

In the Commissionerate schools for Afghans in Pakistan, dropout rates are similar to those in Afghanistan. In NWFP, almost one half the first grade boys do not go on to second grade. Only one quarter of the original first graders are in school by the fourth grade. Dropout rates for girls are higher. In the NGo supported 
schools inside Afghanistan, the majority of students are enrolled in the first three grades, with roughly half the number of students attending first grade still enrolled by grade four. What happens in the first three years of school, therefore, becomes critical to the sustainable impact of the primary education investment (Carter).

High wastage rates reflect the quality of teaching and learning, the condition of faclifties, and problems in the larger economic and political environment (see 2.4 below). Wastage is cost inefficient and taxes 1 imited resources available for education. While wastage rates do indicate the ineftlciency of existing formal primary education, years of school attendance or even completion of primary schools do not automatically equate with sustainable literacy.

Other Access Indlcators - Gender and location/ethnic group also appear to influence access to primary education. In rural Afghanistan and among refugees in Pakistan, gender is clearly the most important factor influencing primary school attendance; in the Commissionerate schools in Pakistan there are 14 times more males than female students. Within Afghanistan, at schools supported by NGOs, attendance by girls is largely precluded by the absence of female teachers.

Language, location and tribal background influence access in different ways. The refugees in Pakistan come predominantly from Pashtu speaking areas. Instruction in commissionerate schools, which provide about half the refugee education, is in pashtu, not Dari. While some of the tanzeem (political party) schools offer instruction in Dari, Dari education is less accessible to Dari speaking refugees than is Pashtu. Within Pakistan, more schools are concentrated in NWFP, where refugees come largely from the Eastern provinces. Balouchistan, with fewer schools, has refugees largely from the southern provinces. Among the schools operated by the NGOs inside Afghanistan, fewer are located in the south, partly because of insecurity and heavy damage. The largest number are in Ghazni, Wardak, Logar, Badakhshan and Baghlan. school location reflects security factors, support of the local military commander, or local demand for education. Thus Wardak and Logar with a largely Pashtoon population and which tended to have fewer primary schools than other provinces in the pre-war pertod, now have more: Badakhshan and other northern provinces with a heavy Tajik population had relatively more primary schools in the prewar period, and continue to give relatively high priority to

In the Kabul Government school system, the number of primary schools is blased toward Kabul City. within the city, the newly arrived, displaced populations have less access than estabilshed residents, and particularly families with education and government
jobs. 


\subsection{Education Policy and Btructure}

A plethora of policles and formal primary systems for Afghans are presently apparent. Analysis of the current Afghan conflict focuses on the politicization of education policies as evidenced in curriculium and in the rapid and forceful inclusion of females in education following the 1978 revolution. While the proactive education policy of the PDPA Government distinguishes it from previous governments, such distinctions should not obscure the recognition of all modern Afghan governments of a link between education and national development. The pre-1978 governments had specific commitments, not always vigorously implemented, to education as a means of producing the skilis and outlooks necessary to modern production and management. At present, the protogovernments of the mujahidin, the Afghanistan Interim Government (AIG) In Peshawar or the evolving governing structures established by some military commanders, are developing their own education systems, whether in response to demand for religious education, or to meet their own needs for skilled manpower to carry on the war. Differences will remain among Afghans as to education for what and education for whom even should Afghans be reunited under one government. At some level there is a minimum demand for formal education: for middle class and emerging middle class families of various political allegiance, the demand for formal education is strongest.

Lacking a single, strong state for all Afghans, a varlety of educational systems have emerged which combine elements of the pre1978 school system with characteristics of the ideology of the governing group. Thus the school system operated by the Government in Kabul, while reorganising the length of primary and secondary education, retains the essential structure of the pre-1978 Government. It still has an urban and secondary bias, reflecting the demands of its urban middle class power base and serving 1 ts ideological goals. It also has a new bias toward female education. Among resistance groups there are varlations in systems depending on location, ethnic group and level of demand for education. Ali rely on the pre-1978 curriculum as the base for at least part of the curriculum. The emphasis is on religious, primary and male education, reflecting the largely rural nature of the refugee population as well as the ideological outlook of the mujahidin leadership in Peshawar.

While the Government of Afghanistan operates schools from Kabul as one system, there are a varlety of systems serving refugees and rural Afghans. Each may have its owr management, hiring, supervisory, supply, currlculum and other functions. Most of the education for refugees in Pakistan is provided through two types of systems. For one, UNHCR supports the Government of pakistan Commissionerate for Afghan Refugees and its Education Celis in 
Peshawar and Quetta to operate schools for about half the refugees separately through Tanzeem or party schools, which are operated as large a group of stutical parties in Peshawar, serve nearly political parties run their both secular and religious own school systems whlch may include some support from NGos, frequools. The tanzeem schools recelve There are a few private schools books, materials and salarlés. Province, operated by middle , mostly in North west Frohtier supported by NGOs, as wellade class educated Afghans, often refugees.

The systems which operate schools inside Afghanistan are perhaps coordination. and varied, and also lack comprehensive formal schools which There are nine major NGos supporting cross border leadership and oftate through local military and/or community parties. The largest conjunction with Pakistan based political Alliance which was est of these is the Education center of the University of Nebraska. teams of monitors and. The ECA maintains a staff in Peshawar and NGOs supporting school systers inside Afghanistan. other major Committee, and Muslim Aid.

2.4 Onderlying Causes - Low Performance and Coverage of Formal primary
Education

Behind the continuing poor performance of formal primary education systems for Afghans lie a complex of reasons. Immediately relevant are the generally low qualifications of teachers; inappropriate curricula and pedagogy: inadequate school facilities, books, supplies and teaching aids; lack of recurrent budget; and the attitudes about insecurity. Beyond these, family economic needs, concepts of the purpose of educationy for girls, and divergent group or location, also influcation, which may vary by ethntc output.

\section{4-1 Teacher, Numbers and oualifications}

Afghanistan entered its period of civil war with a shortage of qualified teachers. War itself has killed an estimated 2000 inside Afghanistan, primarily to fighanistan or have been displaced for Afghans there is a shortage of In all schools operated qualifications, and, except for schools teachers with formal Government, a shortage of female teachers operated by the Kabul of mastery of the content of subject matter observers note a lack teaching and learning techniques, management skills. 
In schools operated by the Kabul Government there is a clear movement of teachers into Kabul city and away from the provinces as indlcated in Table 17 .

with. the majority of teachers in Kabul city, Ministry of Education officials report difficulty in recruiting teachers to serve in other provinces. Female teachers represent $56 \%$ of the total, but of these, 758 are located in Kabul.

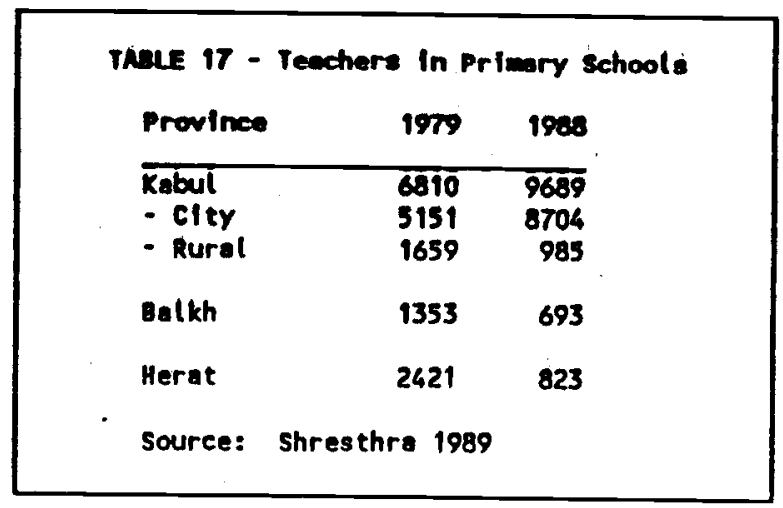
About 35\% of present. primary

teachers are regarded as academically qualified and trained. At the same time output of trained teachers is declining, with about 900 graduates each year. The Ministry presently is exploring recruitment of 12 th grade graduates to be posted in the provinces following short-term training.

Teachers in the various schools operated for refugees in Pakistan are predominantly underqualified. Agencies involved in training teachers have noted difficulties of trainees in reading Pashtu (their native language) or in carrying out basic arithmetic functions. The Education cells in Quetta and Peshawar which manage the Commissionerate schools aim to hire twelfth grade graduates. As certification is not avallable, all applicants, both Afghan and Pakistani, take a written exam which covers materials presented in the schools up through the fifth grade. of the 3014 Commissionerate teachers, about two thirds are Afghans. In the tanzeem (party) schools as many as $90 \%$ of teachers may be first time teachers, lacking basic classroom organization skills as well as knowledge of methods of teaching beginning reading and writing. The shortage of female teachers is most severe. In 1988 there were no female teachers (or girls' schools) in Baluchistan. There were 80 female teachers in the Peshawar area and a smaller number in the camps; of these about 30\% were teachers before the war. The commissionerate employs about 100 Pakistani female teachers. (Carter).

Comprehensive figures on the number of teachers working at the 2000 schools supported by nine NGOs Inside Afghanistan are lacking. In 1988,2896 teachers were working at schools operated by seven NGOs (excluding the Education Centre of the All lance and the University of Nebraska (ECA/UNO). In general, teachers are presumed to be under qualified. Data collected by the ECA/UNO on theit teachers suggests that $33 \%$ have less than a secondary school degree. The Afghan Education Committee estimates that most of 1 ts teachers have less than a secondary degree. There are variations among the provinces as to the avaliablitity of quatifled teachers. The best 
supply of qualified teachers may be in northern provinces not heavily damaged by the war and where education has traditionaliy teachers in Afghanistan supported There is no data by gender on a substantial majority are male.

\subsubsection{Training}

With the low quality as well as shortage of teachers in all systems, there is a need for in-service and pre-service training. As noted before, the output of teacher training institutes of the Education officials indicate the need for expertise and resources to design and implement short-term, practice based training courses
(Shreshthra 1989).

For refugee teachers in Pakistan the Education cells of the training ranging from a fith several NGOs have given in-service t.sachers. Content focuses on bours to four months to some 3000 methods. The only agency offering subject matter and teaching Islamic Relief Agency (ISRA) with a pre-service training is the for secondary school graduates.

In-service training as well as supportive supervision for teachers In Afghanistan are complicated by the difficulties of working across border and of lengthy transport times in Afghanistan. Nonetheless, teacher training is beginning inside Afghanistan. The teams. Muslim Aid, ECA/UNO and organized several mobile training while Muslim Aid is exploring estabe also organizing programmes institute in the North (Carter).

\subsubsection{Curriculum, Pedagogy, Texts and Teaching Aids}

Teacher qualifications are inextricably I1nked with curriculum and teaching methods. Teachers who do not themselves read and write learning process, derived trional perceptions of the teaching and learning the Koran common to mosque and repetition method of participation and mastery of materlai and skilis, IImit, student used in most Afghan primary schoois falls intolis. The curriculum first is the currlculum used in Kabulis into two categorles: The secular and inciudes political content Government Schools which is similar currictila used in refugee and second are the largely schools, derived from prewar curricula cross border operated instruction. Teaching methods practiced and including religlous centered methods require greats practiced are largely rote; child of time. 


\section{Kabul Government Curriculum}

Following the 1978 revolution in Afghanistan, the Government revised the curriculum to include political content which was and continues to be offensive to portions of the Afghan population. In 1989, the Department of Curriculum studies in the Ministry of Education began work on revision of the primary school curriculum. The proposed revisions are not yet avallable. The Ministry indicated to UNICEF the need for technical support in designing curriculum relevant to the needs of children. At present the curriculum development process is highly centralised and not based on an empirical needs assessment, involvement of provincial education officers, or the flexibility to adapt curriculum to local needs (Shresthra 1989).

Because of scarcity of paper and other materials for printing, text production is at an estimated three fifths of current need. The supply of teaching aids, from primary school kits which include charts and manipulable materials to chalk, has almost ceased. The lecture method is used in primary schools and instructional hours are limited because of school closures and the need to use school buildings for two or three shifts.

\section{Pakistan and Cross Border Curricula}

While there appears to be an enormous variety in the curricula used by the multitude of agencies involved in cross border and refugee education, they are nearly all based on the pre-1978 Afghanistan curriculum. Islamic studies and the Holy Koran, the mother tongue (Pashtu or Dari), and math dominate the curriculum, with Pashtu instruction more common in Pakistan and in the Pashtoon areas cross border. The major exceptions to this pattern are the Commissionerate schools where the curriculum combines the pre-war Afghanistan and the Pakistan Government curriculum. These schools offer only Pashtu and begin Urdu in the first grade. The Commissionerate Schools also begin health instruction in the first grade; in other schools health comes only in the fourth grade, if at all, after many students have dropped out. Religlous subjects are important in all schools.

In most cases the curricula are not written out as a guide to teachers; but are derived from the textbooks (Carter). Textbooks are produced with support from the NGO groups involved in education as well as the Government of Pakistan Commissionerate. The texts avallable do not all proride enough information for teachers who lack mastery of the substance; others rely on examples or plctures foreign to the everyday world of the students; and some have unclear print. The legacy of deeply held resistance among refugees to the curriculum introduced by the Kabul Government after 1978 makes curriculum development sensitive. Religion remains an issue, and the involvement of foreigners. In curriculum developmetit threatens its acceptability. There has been some experimentation 
with child centered primary materials and visual aids (Pak-German Bas-Ed materials) and these are being used in some Commissionerate Schools. Adequate supply of books and materials to schools inside Afghanistan is difficult because of the transport problems
involved.

\subsubsection{Bchool Faclilities}

War has been devastating to the school infrastructure in Afghanistan; about 2000 school buildings have been destroyed. This and war has further pre-1978 school system operated was inadequate, Plan (UNICEF 1977) depleted school infrastructure. The Seven Year buildings and facilities. A UNICEF 708 of schools lacked proper found that only $5.8 \%$ of schools UNEF analysis of 1974 survey data a latrine, few of which were of sanitaccess to safe water; $33 \%$ had

Presently, out of the 533 prtmary Government, $45 \%$ operate without 533 primary schools operated by the Kabul only $10 \%$ are housed in government bullding or in temporary sheds; operate in rented facilities, mosques structures. The remainder by government and the community.

within rural areas of Afghanistan, the Salam Missions, flelded by the office of the Coordinator for United Nations Humanitarian and Economic Assistance Programmes for Afghanistan report substantial damage to schools structures. Heavlest damage has been in areas of intense bombing, including Kandahar, Herat, Laghman, Nangahar of the policies of the Kchool buildings were seen as symbolic mujahidin. NGOs supporting schools Government and so destroyed by an increasing demand for schools inside Afghanistan now report reasonable security.

\subsubsection{Reading vaterials}

The severe shortage of reading materlals avallable for Afghans achileved constrains the capacity to malntain literacy when it is skills.

\subsubsection{Attitudes and Values}

Attitudes about education in general, and for women in particular, are a principal contributor to the low efelciency of education for within Afghan society. the controversial position of education sending chlldren to schor rural Afghans, the primary reason for Rarely was education seen as having been for religlous education. 
at school might have to compete with other demands for the child's labour. Carter notes the popularity of religious education at madrassas or mosque schools among Afghans in Pakistan. Religious instruction includes customs, social norms, hyglene, family responsibilities, $l$ aw and history preparing children to live in an Afghan society. Education is less valued for girls than for boys. Parent requirements for all-girl schools, reluctance to allow girls to walk to school any distance and household demands for the labour of girls limit their access to education. A demand for education has been more deeply grounded among non-Pashtoon groups in the North of Afghanistan and indeed statistics for the pre-war period show a higher particlpation rate there. Among the growing urban middle class the demand for education was high, including for girls, and especially for secondary and higher education.

Governments have made the link between education and development, seeing education as the means to produce both the skills and the outlook needed to operate and manage modern economic activities. The PDPA Government which came to power in 1978 began aggressively to use education as an instrument of rapid economic and social modernization. It was this politicization of education as percelved by many traditional Afghans, that led to the rebelition. schools were destroyed by mujahidin as symbols of a communist, anti-God regime.

The mujahidin opposition to schooling carried over to the refugee experience in Pakistan. While a refugee school system has emerged, religious instruction occupies between 20 to $52 \%$ of class time in refugee schools (Carter); forelgn support to curriculum development or textbook content is suspect; and girls' schools and female teachers have faced violence and threats of violence from fundamentalists among the refugee parties.

Carter suggests that attitudes among the mujahidin toward education have been changing over time as the war has continued to disrupt what were normal education patterns, prolonging the unmet demand for education. Moreover, working with sophisticated weapons during their campaigns, the mujahidin have come to recognize the value of schooling (Carter). Among a selected sample interviewed by Connor for the Afghan women Refugee skills survey, these largely middle class women with some training placed high priority on education and suggested several avenues of advocacy to persuade Afghan men of the value of education for women.

\subsection{Post Primary Education}

Political and social division along with the consequences of war have markedly changed the orientation of and access to post primary education. With the exception of secondary schools operated by the Kabul Government, opportunitles for post primary decreased for Afghans. For women, access education have has increased 
dramatically in areas controlled by the Kabul Government at the same time as it has been curtailed in rural areas and among the refugee population.

Data from the Government of Afghanistan show a remarkable increase in the number of middle and secondary schools between 1979 and 1988, even though the geographic base covered by the Government school system is smaller in 1988 as indicated in Table 18 .

In 1978, iemales represented 19.5\% of lycée students (UNICEF 1978) by 1984-85, they were $32.7 \%$ of lycée students and $35.5 \%$ of the graduates (Basu). At the university level in Kabul, women represent more than $50 \%$ of the students as against $12 \%$ in 1977 .

Secondary education in rural Afghanistan has largely broken down due to the civil war. Where secondary schools operate, the facilities are damaged and the students are male. There are exceptions to this, as with a 1000 student girls' secondary school reported in Badakhshan. Comprehensive data is not available. Among refugees in Pakistan, secondary education for Afghans is Iimited and efforts to establish secondary schooling for girls in Peshawar have encountered resistance from fundamentalist groups. Limited opportunities for study overseas have been made available to refugees, selected often through the Peshawar party leadership.

\subsection{Non-Formal Education and Modalities}

Non-formal education has followed different objectives and strategies in the Kabul Government areas and among refugees and cross border programmes. The Government in Kabul uses non-formal methods as a primary tool to promote literacy (see above section 2.1) and the values of the People's Democratic Party of Afghanistan (PDPA), relying on mass organizations, including womén's organizations, as vehicles for mobilization and training. The Afghan Women's Council (AWC), for example, reports 150,000 women members throughout Afghanistan and offers training in 1 teracy and in income related skilis such as secretarlal work, hairdressing and sewing. AWC offers legal advice and support to women and seeks to raise women's consciousness of their rights and opportunities. The AWC is presently seeking a less political and more service oriented role than it previously held (Moghadam 1989).

Among refugees; most non-formal training has been in support of health or education programmes implemented for Afghans and requiring Afghan participation, or to create income generating skills. They are a limited substitute for the nurse, health worker 
and teacher training which occurred before 1978. Income generating skill training for women has focused on handicrafts; exploitation of the skills remains dependent on supplies, marketing and quality control provided by NGos, resources which may not be sustainable for the longer term. There has been some experimentation with alternative methods to make education accessible to girls. The International Rescue Committee, for example, has been organizing first grade classes held in private homes in order to make it possible for girls to attend. Literacy training; as opposed to more formal primary school approaches, is 1 imited. Save the Children (USA) initiated a youth literacy programme for about 450 children age 10-14 (Carter).

\subsection{Emerging Issues}

The fragmentation of educational systems and approaches is a response to the reality of a weak national state, differing priorities and the constraints resulting from war. Emerging from the fragmentation are issues basic to planning for the future.

Models for Future Education systems

All systems of education currently in operation represent the adoption of a formal primary education model borrowed from the West. Carter (1988) notes that there has been little questioning among refugee and cross border education groups of "the usefulness of traditional primary education to peasant communities". From observations on the Kabul side, shreshthra suggests that the Government has given little consideration to non-formal methods as a way of increasing equitable access to basic education for Afghan children. The traditional formal education system is costly. The data on wastage suggests that formal education in Afghanistan has been and remains cost inefficient, and ineffective in producing permanent literacy.

Financing Education

Resources and willingness to commit them determine the capacity of any government authority to implement an education policy. The Kabul Government school system operates with a severe shortage of recurrent and capital budget. Resources for refugee and cross border education are swollen by external support and may not be sustainable in the long run.

Current data on school financing In Kabul is 1 imited, but the data do suggest both inadequacy of total resources and inefficient allocation of available resources. Capital investment in education is low, 114 million Afghanis or about $10 \%$ of capital investment in the social services sector. Expenditure per child per year in primary education is Afs.16,000 and Afs.8,000 per child in an accelerated primary programme for out of school chlldren. By contrast, cost per child in a state supported kindergarten is Afs.42,000 per child (Shresthra 1989). 

Data on cross border school financing suggests a heavy reliance on
external funding (Carter 1988).

\section{Female Education}

The public role of Afghan women will continue to be a political issue. What may be different is the exlstence of several, not necessarily united, groups of women, and their families, which to some degree articulate a demand for female education. (cf. Connor,
Dupree, Moghadam).

\section{Women's Groups}

Though programmes for women are politically volatile, women's organizations have been a part of modern Afghanistan. The Women's Institute in the pre-1978 period, like the Afghan Women's Council until perhaps recently, have been associated with the political Women's Informal some of the refugee parties have women's wings. Because of the utility of have existed at the village level. information to women and for women's groups as a channel for remain a potentially powerful tool. 
PART V - BNDORINC BTROCFORAL CONBTRAINTB ON BEALTA AND EDOCATION DEVELORMENT FOR CAIIDREN AND NOKEN

\subsection{OVERVIBN}

Several enduring factors constrain, for the long term, any efforts to improve the situation of children. The extreme poverty of the country along with a weak resource base limit the capacity to invest in or malntain child survival, health and development programmes. There is a continuing tension among Afghans between modernizing and traditional tendencies and between efforts to bulld a national state and a modern bureaucracy and to maintain the local political and military power or traditional or tribal leadership. Deep rooted patriarchical attitudes and practices will continue to limit Afghanistan's human resource potential and will be a constraint on child survival and development interventions. Geography, limited infrastructure and low literacy will work to continue the developmental, cultural and intellectual isolation of much of the Afghan population.

\subsection{POVERTY}

Prior to the present conflict, Afghanistan ranked as one of the poorest countries in the world. In 1978, the world Bank estimated per capita Income at US\$160. A 1986/87 United Nations estimate of per capita GDP was US\$130. The meaning of Afghanistan's poverty can be measured by the 1 imited data on macro-economic trends, and on the agricultural, industrial, mineral, infrastructural and human resources of the country. The impact of the poverty is and has been felt unevenly. Pre-1978 surveys found 20 to $40 \%$ of Afghans living below the poverty line; $6 \%$ of households in Kabul received more than 50\% of income (UNICEF 1978). A 1973 UNICEF study of village life highlighted the economic dependence and isolation of villagers. The poorest 22 of 42 households (52\%) in Ri-Jang owned less than $5 \%$ of total goats and sheep, $13 \%$ of the land and only $15 \%$ of total income. Unable to subsist on their own land, they worked as hired labour or as sharecroppers (CINAM). Cold winters combined with poverty to aggravate the impact of poverty. observers reported viliagers' use of opium in Badakhshan to numb the pain of cold and hunger (L. Dupree). Revolution in 1978 and more than a decade of conflict have changed aspects of poverty, but the human impact remains and has particular intensity in rural areas heavily
bombarded or among dislocatees in Kabul.

\subsection{Macro-Economic Trends}

Afghanistan is an agricultural based economy (45\% of GDP). The performance of the economy has been declining at a rate of $2.6 \%$ a year, largely due to declines in output in agriculture,
handicrafts, trade and transport. 
Agricultural production fell on average $2.6 \%$ per year, with the heaviest decline in the 1978/79-1984/85 period when the greates $t$ emigration occurred. Handicraft producdeclined at an annual rate of 2.48.

During the
$1978 / 79$ to
$1986 / 87$ period,
the Government
has seen a
large increase
(98 in real
TABLE 19 - Gross Domestie Product at Constant 1978/79 Prices (aittion Afghenis)

197979 share of cDp

$1906 / 87$ (x)

Agr icul ture

Mining Industry anergy

Construction

Transport Communications

Trade Distribution

Others

Total Production

Services

Private

Public

Housing

Total Net Domestic Production at Cost

Depreciation

61,900

14,400

4,300

3,000

9,700

1.700
9.500

45.5

\begin{tabular}{rr}
49,000 & 45.5 \\
14.465 & 13.6 \\
4.800 & 4.4 \\
4,800 & 2.7 \\
9,100 & 8.5 \\
1.700 & 1.6 \\
\hline \hline 2.151 & 76.4
\end{tabular}

\section{4,775}

4,500

4,102

9,140

3.8

5,730

4,922

8.5

110,505

6,700

100,315

7,400

4.6

TOTAL EDP

117,207

107.715

6.8

100.0

Source: UNOP Estimates 1988

terms) in government recurrent expenditure, while government revenues are estimated to have remained constant in real terms. Increased.government expenditure resulted from military expenditure, expansion of government employment and wages; and subsidies for basic items mostly for the urban population. a low level, growing at a nominal rate of 98 per year. Budgetary deficits have been financed through foreign assistance and borrowing from the Central Bank, which resulted in higher
inflation.

The consumer price index reached an estimated 280.9 in $1986 / 87$ $(1978 / 79=100)$. Government policles have controlled basic food prices, particularly in urban areas through subsidies of wheat, bread and sugar prices and through provision of basic items to civil servants at subsidized prices. Though the value of the Afghanl has been held by Government at Afs 50 to the US dollar, the free market value has risen to US\$1.00 = Afs 554 .

Development expenditure during the $1978 / 79$ period has in real terms fallen by an estlmated $5 \%$ per year. Only $9.1 \%$ of development expenditure has gone to agriculture, while 428 has gone to mining,
industry and energy sectors $(1986 / 87)$.

Afghanistan traditionally had a low level and narrow base of taxation, with more than three quarters of its taxes coming from foreign trade. In recent years an increasing source of governifint revenue has been the sale of natural gas to the USSR. 
Afghanistan's trade Imbalance has widened since $1978 / 79$ as Export of natural gas rove exceeded the increases in exports. $1978 / 79$ to $54 \%$ of total Central Bank fell fral exports in 1985/86. Gross reserves at the in 1986/87. (UNDP 1988).

\subsection{Agricultural Resources}

Agriculture was and remains the base of the Afghan economy. In 1977 it produced $55.8 \%$ of net national income. In 1986/87, it was 458 of GDP. In 1978 the World Bank wrote optimistically of Afghanistan's capacity to mobilize its agricultural resources to feed and clothe its people and to expand exports. In 1974, Afghanistan had begun to produce enough wheat for domestic needs and agricultural exports were more than twice the value of nonagricultural exports. By the late 1980's, data from the 75-80\% of the country not controlled by the Government in Kabul suggest that agricultural yields have fallen by more than half (Swedish Committee for Afghanistan 1988). Comprehensive figures on production trends are not available, but officlal Government data along with data from independent surveys suggest significant declines in wheat and other grain, fruit, cotton and sugar beet production. Reductions in production can be traced to declines in the agricultural labour force of 25-30\% and in areas under cultivation by 20-30\%, as well as lack of inputs. War and refugee flight have destroyed the country's capacity to feed itself. Wheat imports recently averaged 250,000 tons per year (UNDO 1988). Production capacity is insufficient to sustain returning refugees.

Livestock have traditionally been a major part of agricultural production, the basis of the nomad economy, and a traditional indicator of wealth. An estimated 5 million animals have been lost during the war and another 1.5 million taken out of the country. This includes a loss of nearly $70 \%$ of Afghanistan's karakul sheep population along with substantial reductions of goats, cattle and, draught oxen is estimated at 40-50\%, aggravating the problem of farm labour shortage resulting from large scale rural emigration. The decline in livestock is due to sale of livestock to finance emigration or living costs; losses due to bombardment, mines, or shooting by the army; or decline in animal health services and increase in animal disease (UNDP 1988. and Swedish Committee for
Afghanistan 1988).

Geography and climate limit the agricultural resource base of Afghanistan. It is a country of rugged mountains, rising to 20 , odo climate brings hot dry summers and east. An arid continental ranges from $100 \mathrm{~mm}$ per summers and cold winters. Precipitation 
$1000 \mathrm{~mm}$ in mountain areas. Precipitation is concentrated in winter and above 9000 feet occurs largely as snow. Precipitation varies season. Irrigated land produces mot well distributed within the of the country's 65 million hectares, only 808 of all crops. Out of these only about half were planted in $8 \mathrm{milli}$ ion are arable and of water and the need to allow rainfed normal years due to lack Afghanistan has iimited forests in pactialds to remain fallow. forest resources have been destroyed and Kunar Provinces, but decade at a rate ten times the capacity and depleted in the past the rest of the country has been used for regeneration. Much of and access to inputs also factors, land tenure, irrigation systems, World Bank in 1978 noted that --large land holdings farmed by farm ownership and tenure patterns with small fragmented holdingsecroppers and tenants combined improvements to raise low yields. In office noted that $5 \%$ of households In 1978 the central statistics and that there were 666,000 landiess $45 \%$ of agricultural land landlords under tenancy arrangements to retain one sixth to one elghth wich might have allowed them 1978). Traditional water rights or of their production (UNICEF landowners near the head of canals or distribution systems favor existing water or community improvemd discourage efficient use of debt systems (gerow) also worked tonts to systems. Traditional While the PDPA Government following impoverish small farmers. of reforms fueled resistance to the Committee for Afghanistan survey work suggests thent. Swedish became refugees in Afghanistan were work suggests that those who greater land and other resources. the better off farmers with potential to be a constraint, and even and and water rights have large numbers of refugees return to a source of contention, when reality for most Afghan farmers. is also likely to remain a extension, credit, seeds and fertilizer Outreach of agricultural limited Government services to 20-25 was never great. War has suggests that there has been a significant rural areas. Data seed stock, contributing to the decline in yieldine in quallty of

As noted above, shortage of labour has been identified as one of be declines in draught oxen. in production. This is compounded manpower situation in Afghanistan... In assessing the agricuitural of women. In the pre-1978 period, a former not include the role Agriculture noted that the degree of female irrigated, the degree of skill required, fure, whether land was migration from the area creating a demand for labour. He
identified the participation of women in 
threshing of wheat; dusting and plcking grapes and guarding vineyards; digging potatoes; and weeding and husking of corn. Women are not involved in oplum production (Ghafoor - UNICEF 1978a).

opium production is traditional in Afghanistan and its use formerly was 1 imited to low levels of use in 1 imited rural areas. By the $1970^{\prime} \mathrm{s}$, oplum production had become an Important though unofficial export. Return per hectare could be as much as nine times that of wheat. Reports from UN sources suggest an increase in opium production from 250 metric tons in 1977 to 750 metric tons in 1988 . Additionally, there is increased heroin production in the region, and increased use in both Kabul and the refugee camps in Pakistan. The potential profits of oplum production will continue as a distorting factor in the agricultural economy; heroin use will have destabilizing social effects.

\subsection{Industry, Mining and Energy}

The manufacturing sector represents a small part of the Afghan economy, $13.6 \%$ in 1986/87. Manufacturing is to a large extent based on agricultural raw materials. Principal items include ginned cotton, cotton textiles, sugar, and vegetable ofl, plus cement, electricity and chemical fertilizers. Because of decilines in agricultural production, production of ginned cotton, cotton textiles and of sugar has declined by $698,35 \%$ and $18 \%$ respectively since $1978 / 79$. Destruction to factories, cuts in electricity, shortage of spare parts and of skilled labour constrains industrial production.

A principal and readily accessible mineral resource of the country is natural gas. Current annual production is 2.4 billion cubic meters of which $85 \%$ is exported to the soviet union and the bulk of the remainder used for fertilizer production. There are limited reserves (20 million tons) of petroleum in the north and a refinery is presently being built. Afghanistan also has reserves of coal, copper and iron ore. Exploitation of these resources awalt's development of infrastructure to permit thelr extraction and marketing.

\subsection{Human Resources}

A shortage of skilled manpower was a major constraint to Afghanistan's development in the 1970's. More than ten years of war has killed or dispersed a significant portion of Afghanistan's skilled manpower; foreclosed the tralning of a generation of youth, and created ideological divisions among the limited skilied

Shortages of skilled manpower in the health and education sectors 
have been described to some extent in Parts III and IV above. In the pre-1978 period there was a shortage of skilled manpower across the board, particularly for middle and senfor level technical which followed 1978, considerable skilied manpower has left the time, the Governinent or for Europe and North America. At the same institutions of higher learning by a increased the output of including an increasingly significant a rute of about 48 a year, trained skilled manpower is, however, number of women. The newly $25 \%$ of the country controlied by the kabul Gover present to the $20-$ which will be determined by Afghans kabul Government. To a degree rebellion which rend the country also divides, the revolution and into ideologically separated parts. divide the bureaucratic cadre rehabilitation will be to enlist ail One of the challenges of resources of the country.

On another skill level, the principal human resources of the country are the farmers. Traditionaliy, there have been more than a million farming households, most of which are ilifterate and unschooled in the formal sense. Training for farmers has been seen management practices for improved husbandry skills or farm business however, the World.Bank saw theads of households. In the 1970's, more sophisticated farming the need for giving women training in in rural labour shortage situatis, recognizing the role of women Government has had a more encouraging female agricultural extension agents of training and have inhibited significant outreachsion agents; security issues will limit acceptability of women agents female agents; attitudes

In the modern labour sector there have been significant changes since 1978 in non-traditional employment opportunities open to forces, the police, the constructiclpation of women in the armed factory settings (Moghadam 1989).

- 0 MODERNIZATION VERBUB TRADITION AUTONOMY: A CONTINOING TENBION

CENTRAL AUTHORITY VERSUS LOCAL

The emergence of a modern Afghanistan with a strong central strong centralizing force and complete. The tensions between a between modernizing. drives and power of local tribal leaders; practices have been present throughout strength of traditional history. The present struggle between the Afghanistan's modern mujahidin mirrors past tensions. tension is that the forces resisting that is different in today's PDPA Government are also themselves the radical reforms of the authority, and that the particular seeking centrai government conflict may be altering the nature characteristics of this long 
bases.

As Afghanistan never experienced colonial domination, the impetus for national modernization through the use of central government power came from Afghans themselves. Louls Dupree in 1973 described the recent history of Afghanistan as "as plece of real estate trying to become a nation state, its external patterns uncontrollably linked with those of the two great imperialist powers of the region" [Britain and Tsarist Russia] and its internal integration "hampered by a plethora of independent and semi-independent ethnic and linguistic units". Its institutions were kinship not government oriented.

It was Amir Abdur Rahman Khan who established central government influence, though not necessarily control, in the geographic area regarded as modern Afghanistan over the twenty-one year period of his reign (1880-1901). From the Durrani pashtoons, the group which had monopolized political power since the 18th century, Abdur Rahman achieved sway over the country through military and political means. He ruthlessly limited authority of religious leaders; executed opponents; and forced the migration of rebelilous Pashtoons (mostly Ghilzais) to northern, non-Pashtoon areas. At the same time he established a modern system of bureaucracy in Kabul and in the provinces. He encouraged modern national trade and communications by visibly and cruelly executing bandits and thiefs and by improving road communication.

Amir Abdur Rahman Khan established control and extended state power through the use of military power and political maneuvering. Military power at the center was necessary to containing rebellious traditional forces. Successive Afghan governments have had to balance modernization efforts with their willingness and capacity to use force to quell rebelilon. Prime Minister Daoud in 1959 did not hesitate to jail, on treason charges, religious leaders who opposed Government encouragement of abandonment of the vell (chadri) for women. Fallure to neutralize or to maintain military control of rebellious factions was an ever present threat to both reforms and governments. King Amanullah (1919-1929) attempted some of the most far-reaching social reforms in Afghanistan, including unvelling of women, education for girls, liberalization of family laws, and an effort to ban polygamy among government officials. Amanullah was able to control early rebellions to his reforms. In 1924 his forces, partly alded by the use of two aircraft, put down a Mangal rebelifion and brought the leader, Mullah-1-Lang, to Kabul for execution Reform programmes, however, increased resentment among conservative religlous leaders, tribesmen and dissident members of the royal family. A rebelilon beginning in 1928 and supported by religious leaders led to Amanullah's abdication and flight and the brief rule of Bacha saqqao. Mahmud Tarzi, leading intellectual and modernist of early twentieth century Afghanistan noted "Amanullah has built a bedutiful monument without a foundation. Take out one brick and 1 t will tumble down." And 
later "If only he had walted for two years and built up the army as Ataturk suggested, what might he have done?" (L. Dupree 1973).

Mahmud Beg Tarzi is perhaps the most outstanding of Afghan intellectuals who sought to modernize Afghanistan, and who is thought to have had pivotal influence on Amanuliah's constitutional reforms. Tarzi spoke out against European imperialism, but also against the resistance of Muslim religious leaders to change and to learn from western 1deas. "If Islam is worthwhile, it is worthy of challenge", Tarzl said, recalling that Islam carried the "torch of learning" in the Dark Age of Europe (Dupree 1973). At the same time the power of the religious establishment, while it ebbed and flowed, remained a factor. It took strength from tribal leaders or from dissidents or conservatives among the royal family:

Leadership of the present Government in Kabul took modernist reform Ideas from western thought, and particularly the soviet Union. The PDPA came to power in 1978 with a radical agenda for reform and social justice which, when implemented, Ignited or intensified the resistance of religious and tribal leaders opposed to the central government. The PDPA Government has used massive military force to quell the rebelilion, while religious and other leaders have built capacity to resist. The parallels with reform and rebelilon in the time of King Amanullah are instructive, but they do not explain the differences which exist in today's situation.

First, the resistance to the Kabul Government cannot neatly be characterized as the rebelifon of religious and traditional leaders to modern reform and central government power. While the principal mujahidin leadership in Peshawar springs from a religious background, the orientation of the religlous outlook is not just traditional. The leader of the most visible peshawar party, Gulbuddin Hekmatyar of the Hezb-1-Islami, is an adherent of extreme fundamentalist Islamic views. He draws his support from young intellectuals committed to an Islamic revolution and has 1 ittie support among traditional tribal and religious leaders. Another group, the Itihad-i-Islami Party recelves considerable support from Saudi Arabia and 1 s fundamentalist in outlook. The strength of fundamentalists had led to supplanting the Hanafi sunni law, traditional in schools and training of clergy of Afghanistan, with the more rigid and dogmatic Wahabi version from saudi Arabia.

Second, the nature of rural, traditional leadership is in $f$ lux. Traditional leadership, large landowners and khans, have largely left the countryside. Mujahidin military commanders, few of whom are from the traditional power structure, have, because of military skill and the de facto provision of government services in the areas they control, emerged as a new form of leadership.

Third, the years of conflict have built separate Afghan bureaucracies with divergent ldeologlcal outlooks. The Kabul bureaucracy, if not communist, is secular and westernized, and has 
integrated large numbers of middle class women. The Mujahidin bureaucrácies are educated, but fundamentalist in outlook and male
in gender.

Fourth, increasing numbers of Afghans have become urbanised and exposed to modern influences. While mujahidin have been opposed to the modernizing influence of clties, it is not clear that refugees exposed to Pakistan urban life and even employment will return unchanged to their rural roots.

Finally, reform and rebellion have seen the replacement of the Durrani by the Ghilzals as the dominant pashtoon group among the mujahidin and in the Kabul Government. other ethnic groups have emerged in new roles. The hazaras, a long dominated group, have developed their own political parties. The Tajiks and other nonPashtoon groups have emerged as important resistance fighters with strong local political bases. (cf. Roy 1989).

Modernizing reform and the resistance to it have in more than a decade, altered traditional social and power relationships among Afghan groups. While the Afghan loyalty was traditionally local - to tribe and ethnic group--the impact of this rebellion may alter alliances and power relationships in the continuing tension between modernism and tradition, and between local and central authority.

\subsection{PATRIARCHICAL ATTITUDES AND PRACTICEB}

The PDPA Government posed a direct and active challenge to centuries old patriarchical attitudes about women. Women and men in Kabul Government controlled areas have become accustomed to new roles for women, but these reforms are for many Afghans tainted by their association with communist or forelgn ideology. The position of fundamentalist groups toward women, sometimes influenced by Saudi Wahabism, has calcified. Afghan women are left little leadership alternative between two extremes.

In traditional Afghan society, women are valued for their reproductive roles, and particularly for producing the sons who carry on the family line and assure the family's status. To assure that descent, and the honour or status of the family, the honour of the woman is critical. For this reason, Afghan women are traditionally shielded from contact with any outside males through seclusion, veiling, and carefully prescribed gender behaviours. Opposition to education for females is rooted in the need to preserve women's and thus the family's honour. In general, women have accepted their gender role in soclety, and seen the family and children as a desirable focus. In return, women gained from their status some measure of economic and physical security, and often a high degree of respect from men. (Boesen 1989; $\mathrm{N}$. Dupree 1989).

Power in Afghan society is traditionally held by male heads of 
households. There is a clear separation between public and private spheres of ilfe, lin both of whlch tie male head or patiliarch ls the power holder. In the public sphere, power is shared among males, (Moghadam 1989). class, economic level and other stratifications hold the primary respons ogether with the children for whom they mortality and morbidity; yet women bear the greatest burden of spheres. where decisions are made exerclsè no power in the pubilic public resources and which affect the allocations and use of children. While women traditionally the health and welfare of handicraft and other product direct control over the production, they nearly universally lack from $1 t$.

The PDPA gave political priority to women's' issues and saw the need for special measures to single out women "to pull them out of centuries of backwardness" (Government of Afghanistan 1987). Government policles on women, and partlcularly education and Iiteracy programmes, aroused a strong, ldeological response among Afghans, a response based on Islam and serving as a unifylng factor among Afghans. Many observers belleve this resistance movement symbolic value of the physical and psychol honour to Afghan identity, thus making among refugees and moregical seclusion of females more rigid political parties in Peshawar all than it had been previousiy. for females, and some limit women spouse some form of seclusion intensification of conservativism only to family roles. This expressed in harassment and participating in income generating and violence against women 1989 and $N$. Dupree 1989).

The polarization of official attitudes on women between the Kabul Government and the proto-government in Peshawar makes more difficult any child health and survival interventions which are improved health skills health providers and trainers, or on the families.

\section{COLTORAL AND GEOGRAPHIC IBOLATION}

That Afghanlstan has been one of the world's least developed geographic isolation which inhib an inter-related cultural and new ideas.

Mountainous terrain and hard winters isolate large sections of the linked by a paved road circling the construction. The country is the Salang rass and with spurs the central mountains and scaling and Peshawar, and to the USSR to the Pakistan border toward Quetta 
has been damaged during the war, It ls still usabie outslae the major system, there are few paved roads, and some reglons of the country, the Hazarajat and Badakhshan, for example, are isolated for months of the winter. Many Afghans had spent ilfetimes without leaving their villages. Equaliy, government services, sêlálom reached the majority of villages.

physical isolation is re-inforced by a cultural isolation which discourages any expectation of the possibility of change. touls Dupree (1973) spoke of Afghanistan as an "inward looking soclety", where people/ were born to a set of answers rather than to a set of questions. To improve the status quo, people need to question whether it is inevitable (the will of Allah) or whether their actions produce change. The refugee experience in Pakistan and as well as the experience in Kabul; have interrupted the cultural isolation and demonstrated the Afghans ' capacity to affect change in their 1ives. Afghans repatrlated to rural areas will experience again, however, the geographic isolation which contributed to an inward looking society. 


\section{PART VI - PROBLEMS: CONBTRAINTS, OPPORTUNITIES}

\subsection{PROBLEMB:, A REPRIBE}

For the children and women of Afghanistan, there are two critical survival concerns. Of immediate concern if the food shortage or near famine faced by vulnerable groups, chiefly among poor, dislocated populations in Kabul, and probably among pockets of
rural population.

An lmmediate and ongoing survival concern is the high mortality and morbldity rates experienced by Afghan children and women. Mortality has risen in Kabul during the past decade, despite the relative accessibility of health services. Infants in some rural areas may have mortality rates of up to 400 per 1000 live births. Measles epidemics, tetanus and other communicable diseases are major killers, along with diarrhoea, acute respiratory infections and malnutrition. Micronutrient deficiencles, particularly lodine and Vitamin A, malaria, tuberculosis, parasites, eye and skin infections are common and contribute to poor development.

Though not an immediate threat to survival, low 1 iteracy and the low level of knowledge about health and hygiene, are a serious and
indirect cause of mortality and morbldity.

\subsection{TARGET GROUPB}

Principal target groups can be classified by class and income; location; gender; the impact of war; disabilities; and family
status. These include:

- the poorest children and women, particularly dislocatees in Kabul and other cities; refugees in Iran; rural children;

- the perhaps one million orphans and the perhaps $20 \%$ of women who have been widowed, with particular focus on those who cannot be absorbed by traditional social support systems;

- all females, but particularly those from households with the least income and education, whether rural or urban;

- disabled children, women, and women with disabled husbands
or children.

\subsection{CONBTRAINTS, OPPORTUNITIES, MODALITIES}

In ldentifying the constraints, there are also possibilities of identifying opportunities and of ways to maximize opportunities: 
- There will continue to be a weak central government, whatever political resolution evolves. The influences of government will be limited psychologically and geographically. Centres of power may be dispersed. Though a strong state apparatus is generally regarded as a prerequisite to development, the existence of multiple, prot governments for Afghanistan may be a reality for the medil term. UNICEF can use the reality to experiment wit decentralized, innovative approaches to health ana education.

- The fragmentation and even polarization of the Afghan polity and of social cohesion is not easily mended. Interventions accepted by some Afghans will be an anathra to others. Opportunities will lie in approaches which a sorm.-ted, and decentralized, but which have the $c$. building blocks in a national development fr encompasses diversity and different levels of $a-v+\ldots$

- Afghanistan's weak resource and taxing base limits capacity to develop and sustain health and education programmes. Immediate and medium term plans, however, can seize the opportunity provided by the short term avallability of substantial foreign resources to establish the type of health and education systems which are locall: istainable in the long run.

- Attitudes about women and their role vary dely cause for continuing dissension. While $\cdots$ portinc health and education systems which inclur women $\bar{j}$ areas which accept them, UNICEF practical problems of mortality should focus on the productivity in rural areas. morbidity and low health and ideological ducation programmes can be seen, not as an

- Communications and advocacy programmes with male leadership may make both visible and critical the links between women and family health and development. Focus on women's networks and groups may be an avenue to build the capacity of women. Afghan women themselves, if given the opportunity, may identify the ways of increasing women's
access to knowledge and skills.

- Afghan's positive experience with the visible successes of immunisations and with lodine and Vitamin $A$ supplements should be used as a springboard for other interventions and for innovative ways of involving female community health
workers. 
- Negative attitudes to education which have been exacerbated by perceptions of secular education as godless exacerbated wil make outside support to education and foreign Opportunities exist by building to education sensitive. religious education and encouraging positive attitudes to other practical knowledge and teaching reading; and by and by assisting with methods of programmes and communications. 


\section{BIBLIOGRAPAYY}

Rasil Basu, "Planning and Afghan Women: An Educational Profile of Afghan Women" prepared for the UNIFEM-UNICEF Workshop, 21-23 August 1989.

Inger Boesen, "Afghan Women in Repatriation and Reconstruction" Seminar on the Potential for Recovery in Afghanistan and the Role of International Assistance", Geneva, 5-7 May 1989.

Michael J. Casimir, "Animal Husbandry and Rural Development in Afghanistan", Seminar on the Potential for Recovery in Afghanistan and the Role of International Assistance, Geneva, 5-7 May 1989.

Lynn Carter, "Assessment of Current Activities and Priorities in Primary Education and Teacher Training for Afghans", Consultant to UNICEF Peshawar, n.d.

Christian Science Monitor, Shella Telft, "Change Challenges Afghan Women", June 28, 1989; Richard Murphy, "Afghan Village Begins to Rebulld", August 3., 1989.

Hanne Christiansen and wolf scott, survey of the social and Economic Conditions of Afqhan Refuqees In Pakistan, UNRISD, Geneva,

Kathleen Cita, M.D., "A Report on Vaccination Progress in Resistance Held Areas of Afghanistan as of April 1988", UNICEF consultant, April 1988 .

Kerry M. Connor, "Skill Inventory of Afghan Women Refugees in the North West Frontier and Baluchistan Provinces", UNICEF, Islamabad,
December 1988 . Louis Dupree, Afghanistan, Princeton University Press, Princeton,
1973.

Nancy Dupree, "Afghan women and Agriculture", Briefing note prepared for the UNIFEM-UNICEF Workshop, 21-23 Aúgust 1989 .

Assessment") "Women in Afghanistan: Preliminary Needs Women, 1988 !

Economic Intelligence Unit, No. 1, 2, 3/88.

Richard English, "Preliminary Report on Conditions Affecting the Repatriation of Afghan Refugees" "prepared for the operational Unit for Repatriation to Afghanistan, United Nations High Commission for
Refugees", June 1988 . 
Dennis Pigot, M.D., "Health and Nutrition In Kabul, Herat, and september 1989. a Preliminary Assessment", UNICEF Consuitant,

Michael J. Reeves, "Draft Assignment Report, December 5, 1989 to December 16, $1989 "$, Expanded Programme on Immintsation, Democrat id
Republic of Afghanistan, UNICEF EPI Consultant.

P. Rezai, M.D. "Heaith and Nutrition sutvey of Afghan Refugees in the Islamic Republic of Iran", Consuitant Epidemiologlst, UNHCR,

Olivier Roy, "Afghanistan: The social Aspects of Recovery in a Fragmented Society" seminar on the Potentlal for Recovery in May 1989.

Richard B. Scott, "Afghan Social structure and the Development Process: Power and the Rural Scene" mimeo, 1975.

Shresthra, "Status of Education in Afghanistan", UNICEF Consultant,
December 1989.

Marek Sliwinski, "Afghanistan: The Decitidition of a People", orbls,
Winter 1989.

Peter street, "Wheat Price stabilisation and strategle storage Reserve scheme for Afghanistan", UNDP consultant, Kabul; 1977.

M.C. Swaminathan, M.D., "Nutrition in Afghanistan", who Consultant, Swedish Committee for Afghanistan, "The Agricultural survey of
Afghanistan", First Report, May 1988.

Linda Tawfik, "A Proposed Maternal and Child Health strategy for the Afghanistan Health Sector Support Project", Consultait report
to Management Sciences for Health, Boston, 1988 .

UNICEF, "Afghanistan:

(E/ICEF/624), November 1989, Programme Funding Rellef Profect Everywhere", 1988. UNICEF Kabul, "statistical Profile of children and Mothers it
Afghanistan"i, December 1977. Afghantstan", october 1978. Profile of children and Mothers 1H and Kabul", May 1987. 
Dennis Pigot, M.D., "Health and Nutrition in Kabul, Herat, and september 1989. a Preliminary Assessment", UNICEF Consultant,

Michael J. Reeves, "Draft Assignment Report, December 5, 1989 to Republic 16, 1989 ", Expanded Programme on Immunisation, Democratic

P. Rezai, M:D. "Health and Nutrition Survey of Afghan Refugees $1 H$ the Islamic Republic of Iran", Consuitant Epidemiologist, UNHCR, Iran, 1988.

Olivier Roy, "Afghanistan: The Social Aspects of Recovery in a Afghanistan and the , Seminar on the Potential for Recovery in May 1989. Richard B. Scott, "Afghan social structure and the Development
Process: Power and the Rural Scene" mimeo, 1975. Shresthra, "status of Education in Afghanistan", UNICEF consultant,
December ig89.

Marek Sliwinski, "Afghanistan: The Decimation of a People", Orbis,

Peter street, "Wheat Price stabilisation and strategic storage Reserve Scheme for Afghanistan", UNDP consultant, Kabul, 1977.

M.C. Swaminathan, M.D., "Nutrition in Afghanistan", wHo Consultant,
Kabul, 1987 .

Swedish Committee for Afghanistan, "The Agricultural survey of Afghanistan", First Report, May 1988.

Linda Tawfik, "A Proposed Maternal and Child Health strategy for the Afghanistan Health Sector Support Project", Consultant report
to Management Sciences for Health, Boston, 1988.

UNICEF, "Afghanistan: Emergency winter Relief Project (E/ICEF/624), November 1989, Programme Funding office, New York.

Everywhere", 1988. UNICEF Kabul, "Statistical Profile of Children and Mothers in
Afghanistan", necember 1977.

Afghanistan", "Statistical Profile of Chłldren and Mothers in and Kabul", May 1987. 
SICKNESS IN LAST TWO WEEKS AS REPORTED BY RESPONDENTS IN A
. HEALTH SURVEY OF THREE AF AND hElMaND) BY AGE AND SEX

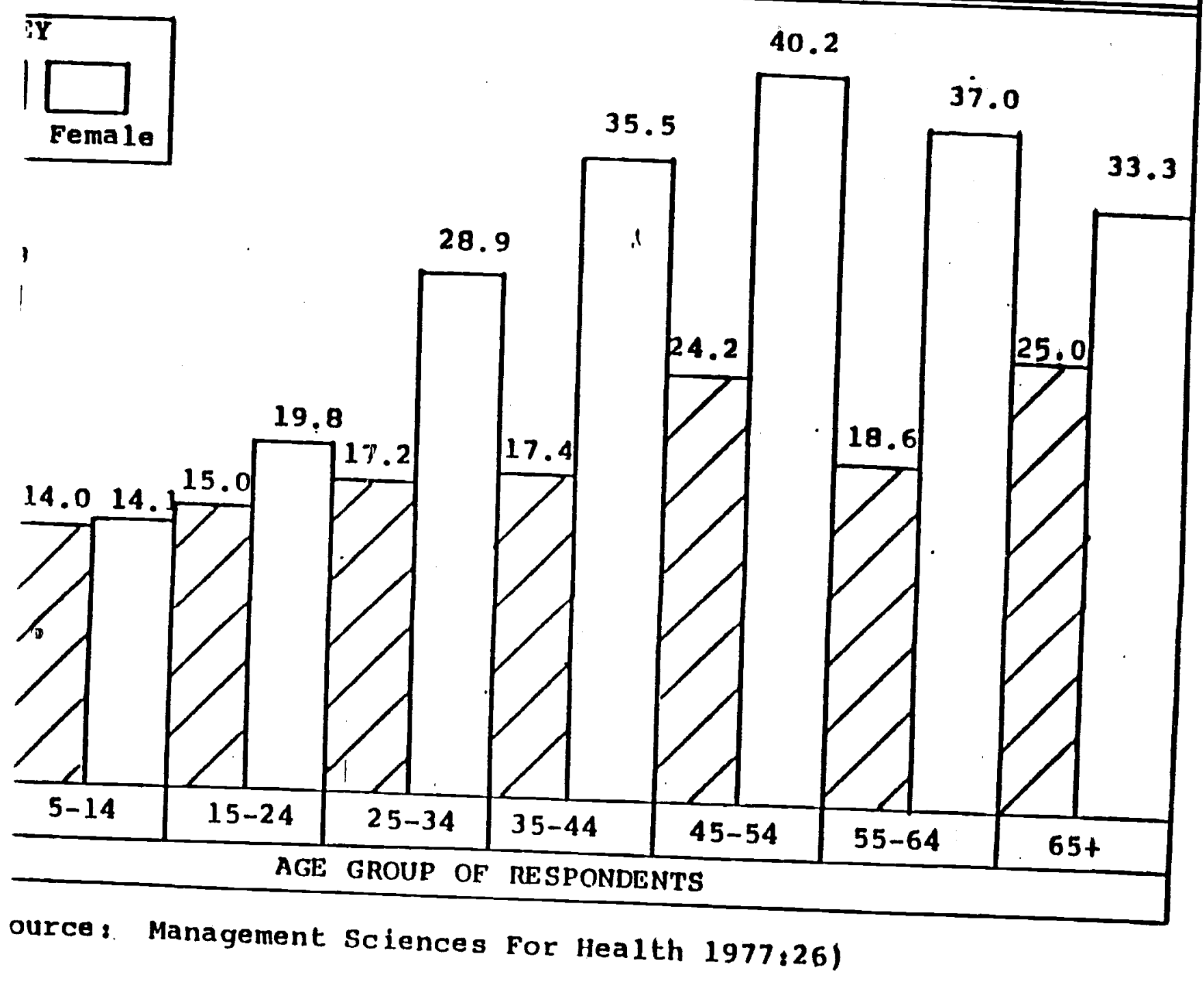


in Afghanistan", August, 1987 . UNICEF Peshawar, "Situation Assessment of Afghan women and
Children", September 1989. United Nations Coordinator for humanitarian and Economic Assistance Programmes Relating to Afghanistan, First and Second Consolidated
Reports, Geneva, September 1988; October 1989.

Assistance to Disabled Afghan, Guidelines and Priorititee on May 1989.

Reports: Appraisal of Existing Water suppion Kabul; Salam 1 - 8-14 December Water Supply to Herat Province and October $=19$ November 1988; Salam 5; Salam 3-Mission Report 7 December 1988; Salam 6-400 km. through Paktika in Kunar, 10-15 1988; An Evaluation Mission to the Panjshir Paktika, 18-23 December United Natons 1988.

United Nations Development Programme, "Draft Discussion Paper Containing Proposals for a Programme of Rellef, Rehabilitation and
Reconstruction in Afghanistan", 1988.

Assistance Programmes Relating of Action, 1990, UNDP Contribution, United Nations Plan United Nations High commissioner United Nations High Commissioner for Refugees, "Report on the
Expanded Programme for Immunisation for Afghan Refugee Health
Programme for 1988", Islamabad, April 1989. USAID, "Afghanistan: Assessment of Current Harvest and Food
Supplies", 1989. World Bank, Afqhanistan: The Journey to Economic Development,
Vols. I and II, 1978. Khin Let Ya, M.D., "EPI Programme: A Preliminary Assessment,
December 1989", UNICEF Consultant, 1989. 


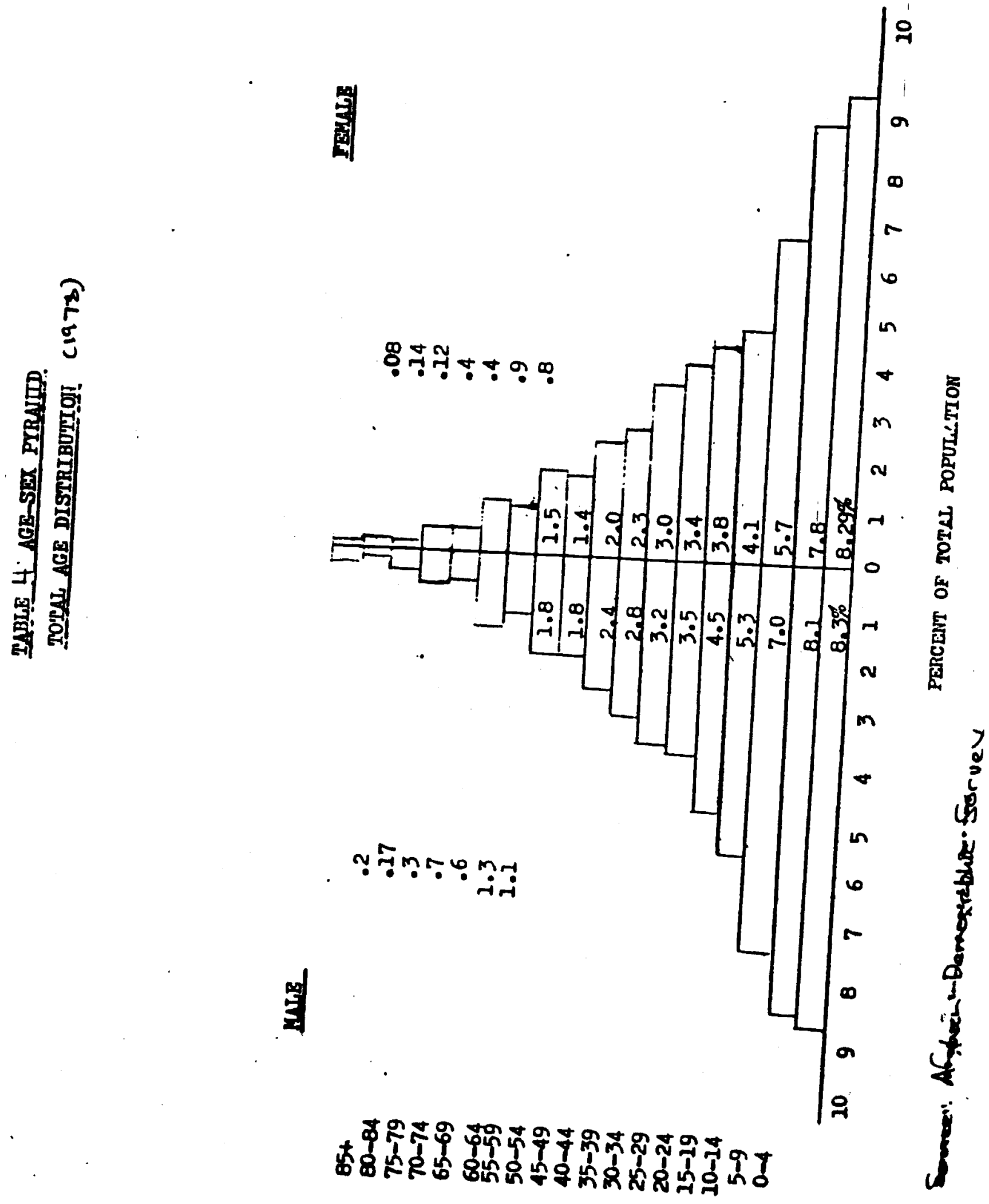




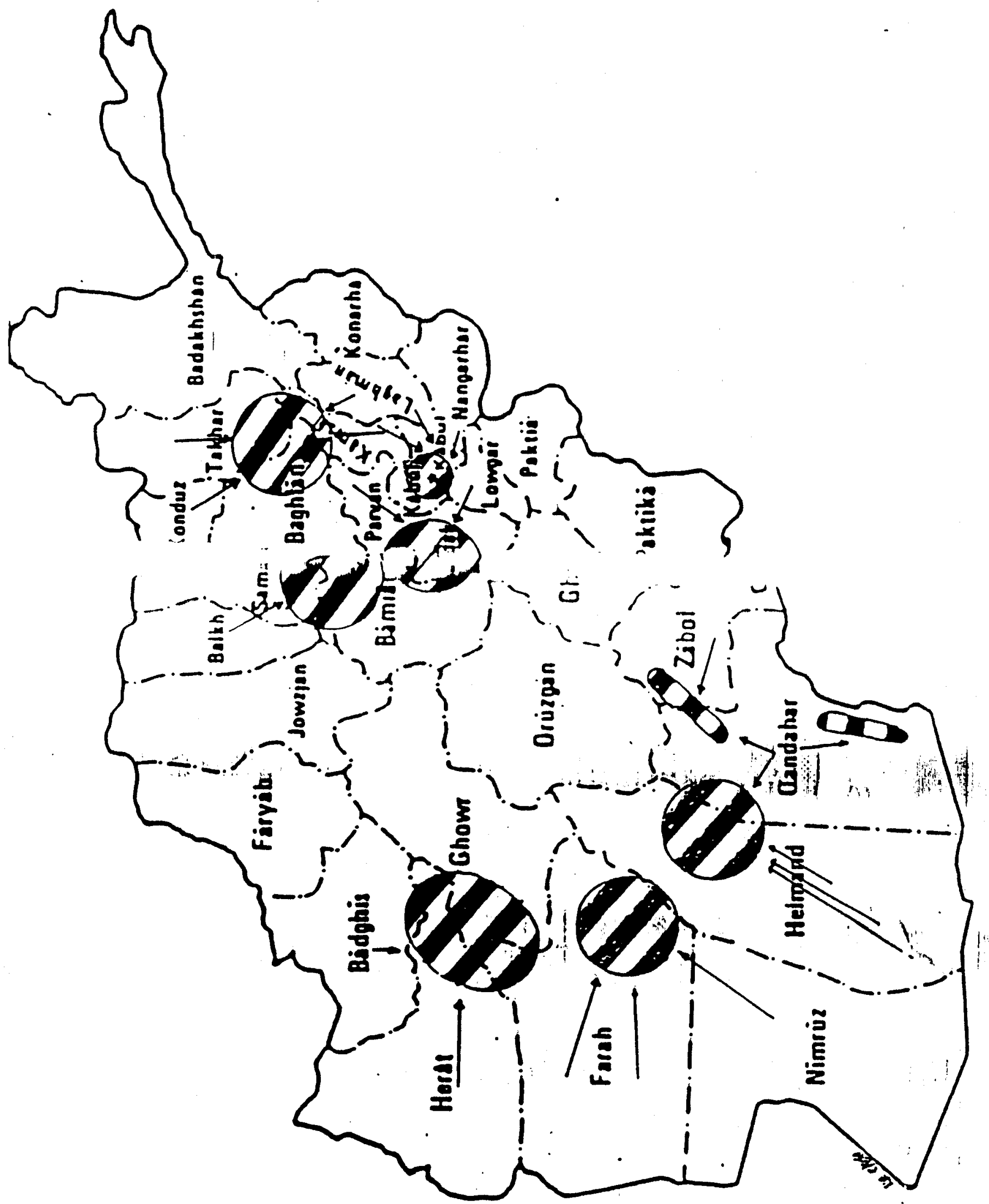

